\title{
Strategies for Microbial Decontamination of Fresh Blueberries and Derived Products
}

\author{
Liliana Pérez-Lavalle ${ }^{1,2, *(\mathbb{D})}$, Elena Carrasco ${ }^{2}$ and Antonio Valero ${ }^{2}$ \\ 1 Faculty of Basic and Biomedical Sciences, Universidad Simón Bolívar, Barranquilla 080002, Colombia \\ 2 Department of Food Science and Technology, International Campus of Excellence in the AgriFood \\ Sector (CeiA3), University of Córdoba, 14014 Córdoba, Spain; elena.carrasco@uco.es (E.C.); \\ avalero@uco.es (A.V.) \\ * Correspondence: lperez70@unisimonbolivar.edu.co
}

Received: 17 September 2020; Accepted: 13 October 2020; Published: 28 October 2020

\begin{abstract}
Increasing consumption of blueberries is associated with appreciation of their organoleptic properties together with their multiple health benefits. The increasing number of outbreaks caused by pathogenic microorganisms associated with their consumption in the fresh state and the rapid spoilage of this product which is mainly caused by moulds, has led to the development and evaluation of alternatives that help mitigate this problem. This article presents different strategies ranging from chemical, physical and biological technologies to combined methods applied for microbial decontamination of fresh blueberries and derived products. Sanitizers such as peracetic acid (PAA), ozone $\left(\mathrm{O}_{3}\right)$, and electrolyzed water (EOW), and physical technologies such as pulsed light (PL) and cold plasma (CP) are potential alternatives to the use of traditional chlorine. Likewise, high hydrostatic pressure (HHP) or pulsed electrical fields (PEF) successfully achieve microbial reductions in derivative products. A combination of methods at moderate intensities or levels is a promising strategy to increase microbial decontamination with a minimal impact on product quality.
\end{abstract}

Keywords: blueberry; processed fruits; non-thermal technologies; chemical strategies; physical strategies; biological strategies; microbial decontamination; quality and safety

\section{Introduction}

Blueberries (Vaccinium spp.) are fruits that are highly appreciated for their nutritional value and high concentration of bioactive substances such as vitamins, anthocyanins, and other phenolic compounds [1,2]. Several investigations have shown that the consumption of blueberries offers health benefits, such as their antioxidant and anticancer effect and protection against cardiovascular diseases and diabetes [3-6]. However, despite their nutritional characteristics, the consumption of blueberries has been linked to foodborne outbreaks worldwide. In Connecticut in 1984, an outbreak of listeriosis was associated with the consumption of blueberries [7]; Calder et al. [8] reported an outbreak of hepatitis A in New Zealand in 2002 where raw blueberries were implicated; in 2006, blueberries and strawberries were identified as potential foods contaminated by non-O157 Shiga toxin-producing Escherichia coli, causing an outbreak in Massachusetts [9]; 14 cases of Salmonella Muenchen infection were linked to the consumption of fresh blueberries in 2009 [10]; in 2010, an outbreak of six cases of Salmonella Newport in Minnesota was attributed to the consumption of fresh blueberries [11]. Likewise, the presence of enteric pathogens in this product continues to be widely reported, such as norovirus and Salmonella in frozen blueberries [12,13].

Blueberries can be contaminated at any point in the production chain. The use of contaminated water and microbial contamination from pickers, food handlers, or equipment during harvest and post-harvest have been reported as prominent factors in the contamination of berries [14]. In this 
respect, some authors have studied the microbiological quality of blueberries and food contact surfaces, i.e., packing lines of fresh blueberries, and found that, out of 310 samples, 46 were positive for enterococci and 27 for faecal coliforms, pointing to these surfaces as potential sources of food contamination [15]. Furthermore, Quansah et al. [16] investigated the microbiological quality of fresh blueberries collected from six different packing houses, resulting in 1 positive sample for Enterococcus and 11 positive samples for faecal coliforms in three of these premises.

On the other hand, blueberries are very susceptible to deterioration due to water loss and mould growth. Blueberry rot is mainly caused by Colletotrichum spp., Botrytis cinerea, Alternaria spp., Fusarium spp., and Penicillium spp. [17-19]. In order to minimize the deterioration of blueberries, consideration should be given to the factors affecting the initial quality of the produce as well as the subsequent handling practices. These factors include the type of cultivar, cultural practices, growing environment and harvesting practices. Following harvesting, storage temperature, humidity and atmosphere are key in preventing early decay, and thus, in extending their shelf-life [20].

Most blueberries are destined for the fresh market; for example, in the United States, the world's leading producer of blueberries, the per capita consumption of fresh blueberries in 2018 was higher than the consumption of frozen blueberries- $0.49 \mathrm{~kg}$ and $0.09 \mathrm{~kg}$, respectively [21]. Likewise, in Europe the demand for fresh blueberries has increased in recent years [22]. However, fresh blueberries are not subjected to any treatment for the eradication of pathogens, and no microbiological standards have been established for these products, which is a serious concern for food safety [16]. Blueberries for the fresh market are generally hand-picked, packaged, and kept at refrigeration temperatures to maintain their shelf-life [23,24]. Nevertheless, fresh blueberries destined to produce derived products such as juice, puree, and dehydrated products, as well as blueberries intended for freezing, are subjected to a sanitary treatment, which classically involves washing with chlorine. Despite the extended use of chlorinated water as a microbial decontamination treatment of fruits and vegetables, alternative microbial decontamination technologies and/or substances have emerged due to issues such as the limited antimicrobial efficacy of chlorine in the presence of organic matter, the formation of toxic compounds such as carcinogenic trihalomethane and chloramine, and its deleterious effect on organoleptic characteristics of fruits $[25,26]$. This has led to European countries such as Belgium, Denmark, Germany, and The Netherlands banning its use [27].

Based on consumer demand for safe food, several investigations have been conducted to develop and evaluate the effect of different antimicrobial strategies on fresh berries, with minimal impact on its quality and nutritional value (Appendix A Table A1). This review summarizes the studies published between 2010 and 2020 on chemical, physical, and biological strategies and the combination of these technologies applied to fresh blueberries and derived products for the reduction and inactivation of hazardous microorganisms and indigenous flora. Furthermore, effects on quality attributes of the products addressed by these studies are presented.

\section{Methodology}

A literature search was performed including published studies between 2010 and June 2020 in the Web of Science scientific database. The search words used were: (blueberr*) AND (Salmonella OR Listeria monocytogenes OR Escherichia coli O157:H7 OR murine norovirus OR norovirus OR hepatitis A OR Cyclospora OR total aerobic bacteria OR yeasts and moulds OR virus OR parasites) AND (chemicals OR solutions OR organic acids OR detergents OR inactivation OR antibacterial effect OR reduction OR decontamination OR sanitation OR disinfection). The search results were reviewed to select those corresponding to the application of microbial decontamination strategies in fresh blueberries and derived products. Additionally, the references of each article were reviewed to complement with other studies in the selected timespan. 


\section{Chemical Strategies}

Chemical strategies are based on the use of different sanitizers or other compounds to contribute to the safety, quality, and shelf-life of foods of plant origin. As previously mentioned, novel microbial decontamination technologies have emerged mainly due to environmental and health problems and the limited antimicrobial efficacy of chlorine. Table A2 summarizes key aspects of published studies where different alternative chemical strategies to chlorine are applied for microbial decontamination of fresh blueberries. In following sections, relevant information concerning the different chemical strategies is presented.

\subsection{Chlorine Dioxide}

Chlorine dioxide $\left(\mathrm{ClO}_{2}\right)$ has been studied as an alternative to chlorine due to its higher oxidizing capacity (2.5 times more than chlorine) [28]. In addition, its effectiveness is less $\mathrm{pH}$ dependent and produces fewer carcinogenic halogenated disinfection by-products (DBP) due to its low reaction with organic matter $[29,30]$. This compound inactivates microorganisms through the destabilization of cell membranes, interruption of protein synthesis, and oxidation of DNA/RNA/protein) [31]. $\mathrm{ClO}_{2}$ can be used both in its aqueous and gaseous form. However, several investigations have focused on the use of gaseous chlorine dioxide $\left(\mathrm{gClO}_{2}\right)$ due to its high penetration, which allows it to reach inaccessible sites where microorganisms are attached [32]; likewise, the treated products do not require a subsequent washing as in the aqueous form, which is advisable for products susceptible to deterioration such as blueberries [33,34].

Among the limitations of $\mathrm{ClO}_{2}$ are the prolonged exposure times needed to obtain significant microbial reductions. Furthermore, the explosive nature of this compound limits its industrial application to some extent $[31,35]$. Other difficulties associated with the cost and on-site generation of $\mathrm{gClO}_{2}$ have been solved in recent years through the development of different methods that allow portable and low-cost generation [32].

Different studies have demonstrated the potential of $\mathrm{gClO}_{2}$ to reduce pathogens and native microbiota in fresh blueberries (Table A2). As an example, Zhang et al. [36] showed reductions of aerobic mesophilic bacteria and yeasts and moulds count (YMC) by $>2$ and $>1 \log$ CFU/g, respectively, after exposure to $\mathrm{gClO}_{2}(4 \mathrm{mg} / \mathrm{L})$ for $12 \mathrm{~h}$. In relation to the inactivation of bacterial pathogens, the cumulative $\mathrm{gClO}_{2}$ exposure of $1529 \mathrm{ppm}-\mathrm{h}$ achieved reductions of $>3.8 \mathrm{log} \mathrm{CFU} / \mathrm{g}$ of Shiga toxin-producing E. coli (STEC), Listeria monocytogenes and Salmonella. Likewise, the authors of that study demonstrated the advantage of using $\mathrm{gClO}_{2}$ under refrigeration temperatures $\left(4^{\circ} \mathrm{C}\right)$ [37]. Regarding inactivation of viruses, a $\mathrm{ClO}_{2}$ concentration of $0.63 \mathrm{ppm}-\mathrm{h} / \mathrm{g}$, achieved the reduction of Tulane virus (TV) in $3.82 \mathrm{log}$ plaque forming units (PFU)/g [38]. It should be noted that most studies have focused on substitutes for human norovirus so there is a research gap in relation to other pathogens such as hepatitis A virus (HAV) which is also involved in foodborne outbreaks due to consumption of blueberries.

Some limitations of the use of $\mathrm{gClO}_{2}$ are related to the bleaching of fruits and vegetables when applied at high concentrations [31]. Kingsley et al. [39] reported that $\mathrm{gClO}_{2}$ produced from concentrations greater than $1 \mathrm{mg}$ of $\mathrm{NaClO}_{2}$ may cause significant alterations in the appearance and quality of the samples. Chai et al. [37] reported that to avoid bleaching of the products, the concentration of $\mathrm{ClO}_{2}$ generated by the dry media method should not exceed $730 \mathrm{ppm}$ (>1900 cumulative ppm-h in a 5-h treatment time). Additionally, processing factors such as exposure time, relative humidity and temperature can influence the antimicrobial efficacy of $\mathrm{gClO}_{2}$ [33]. Sun et al. [40] found a reduction in the efficacy of treatment after 6 days of storage at $10^{\circ} \mathrm{C}$, possibly due to the volatility of $\mathrm{ClO}_{2}$. In contrast, quality attributes such as firmness were maintained [40]. Kingsley et al. [39] also pointed out that the maintenance of relatively low and constant levels of $\mathrm{ClO}_{2}$ in combination with high relative humidity could improve the inactivation of the TV.

In relation to aqueous $\mathrm{ClO}_{2}$, the maximum concentration allowed in the United States for the treatment of fresh products is $3 \mathrm{ppm}$ [34]. However, high concentrations are required to significantly 
reduce the microbial load of fruits and vegetables [33]. For blueberries, it is reported the reduction of initial populations of total aerobic bacteria and YMC in blueberries by 1.4-1.5 and 0.8-0.9 log CFU/g, respectively, by applying $100 \mathrm{ppm}$ of $\mathrm{ClO}_{2}$ for $10 \mathrm{~min}$. However, it should be noted that after treatment, blueberries stored at $4{ }^{\circ} \mathrm{C}$ for 12 days exhibited less deterioration and weight loss and better maintenance of the total anthocyanin content and sensory quality than samples stored at $20^{\circ} \mathrm{C}$ storage [41]. Girard et al. [42] found that $\mathrm{ClO}_{2}$ (20 ppm for $\left.1 \mathrm{~min}\right)$ was less effective in reducing norovirus murine in blueberries ( $<1$ log reduction) compared to peroxyacetic acid $(85 \mathrm{ppm})$ and sodium hypochlorite $(50 \mathrm{ppm})$. To overcome the above drawbacks, combined methods are presented as a good alternative. In line with this, the combined treatment of aqueous $\mathrm{ClO}_{2}(2 \mathrm{ppm}, 2 \mathrm{~min})$ and UV $\left(4 \mathrm{~kJ} / \mathrm{m}^{2}, 3 \mathrm{~min}\right)$ delayed the incidence of decay and improved the quality parameters, thus extending the post-harvest life of blueberries [43].

Overall, $\mathrm{gClO}_{2}$ appears as a promising alternative for the microbial decontamination of blueberries mainly due to its wide range of antimicrobial action, its high penetration power that allows access to irregular surfaces in blueberries, and the possibility of treatment under refrigerated conditions preventing breaks in the cold chain. The controlled release of this substance in sachets inside clamshells combined with refrigeration and high relative humidity also constitutes an alternative for maintaining the microbiological quality of blueberries destined for the fresh market. $\mathrm{gClO}_{2}$ dosages should be established to avoid bleaching effects and other quality defects on fruit. Therefore, it is recommended that microbial inactivation studies also evaluate the sensory parameters in blueberries during storage after treatment with $\mathrm{gClO}_{2}$.

\subsection{Ozone}

Ozone $\left(\mathrm{O}_{3}\right)$ is a powerful oxidant GRAS (Generally Recognized As Safe) that spontaneously decomposes in oxygen. This compound exerts its antimicrobial action through the oxidation of cellular constituents such as proteins, lipids, and nucleic acids [35]. This can be applied to foods in their gaseous and aqueous forms [44]. However, ozone handling has some safety problems due to the risk of explosion and toxicity [45]. In addition, its excessive use can cause undesired organoleptic changes in the products and decompose phytochemical compounds. In this line, Bialka et al. [46] reported a slight darkening of blueberries after treatment with gaseous ozone.

Few studies on the antimicrobial action of ozone in blueberries have been carried out. With respect to the native microbiota, Concha-Meyer et al. [47] did not observe an inhibitory effect on moulds and yeasts in blueberries stored in an ozone atmosphere for 10 days with treatments of $4 \mathrm{ppm} \mathrm{O}_{3}$ at $4{ }^{\circ} \mathrm{C}$ or $2.5 \mathrm{ppm} \mathrm{O}_{3}$ at $12{ }^{\circ} \mathrm{C}$. These treatments did not cause external damage to the fruits, while a reduction in weight loss and maintenance of firmness was evidenced during storage at $12{ }^{\circ} \mathrm{C}$. In fact, similar to $\mathrm{ClO}_{2}, \mathrm{O}_{3}$ can inhibit the enzymatic activity which is responsible for maintaining firmness and reducing weight loss in some cultivars [40,47]. On the other hand, Jaramillo-Sanchez et al. [48] proposed a treatment with aqueous ozone at $18 \mathrm{ppm}$ for $10 \mathrm{~min}$ to decrease fungal decomposition without affecting the weight loss of the fruits during refrigerated storage.

With regard to the effectiveness of ozone against pathogenic microorganisms on blueberries, Pangloli et al. [49] required an ozonated water treatment $(1.5 \mathrm{mg} / \mathrm{L}, 5 \mathrm{~min})$ to achieve a reduction of E. coli O157:H7 of $3.5 \log \mathrm{CFU} / \mathrm{g}$. However, other disinfectants tested, such as bleach solution $(100 \mathrm{mg} / \mathrm{L}$ free chlorine), electrolyzed oxidizing water ( $30 \mathrm{mg} / \mathrm{L}$ free chlorine), and $\mathrm{FIT}^{\circledR}$ solution, showed greater reductions. Concha-Meyer et al. [50] showed a $3 \log$ reduction of L. monocytogenes in blueberries after 10 days of storage in an atmosphere of $\mathrm{O}_{3}(4 \mathrm{ppm})$ at $4{ }^{\circ} \mathrm{C}$. On the other hand, compared to other disinfectants, Bridges et al. [51] showed higher reductions of closed circulated $\mathrm{gClO}_{2}$ than gaseous ozone for pathogens in blueberries (Table A2). The above findings indicate that high concentrations and exposure times of $\mathrm{O}_{3}$ are required to achieve significant microbial reductions.

The combination of $\mathrm{O}_{3}$ with other disinfection technologies could be further studied as an alternative to increase the antimicrobial capacity of this substance. For instance, a synergistic effect was observed by Kim et al. [52], who combined ozone vapor (4000 mg/L; $1 \mathrm{~min}$ ) and ultraviolet light of 
$7.95 \mathrm{~mW} / \mathrm{cm}^{2}$ intensity for $2 \mathrm{~min}$, achieving a greater reduction of E. coli O157:H7 on blueberry calyx (3.05 $\log \mathrm{CFU} / \mathrm{g}$ ) than the independent treatments.

It should be noted that none of the previous studies evaluated sensory parameters or content of bioactive compounds in blueberries immediately after treatment or during storage. Further research should be geared toward finding dosages that maximize microbial reductions without compromising the sensory and nutritional quality of blueberries.

\subsection{Peracetic Acid}

Peracetic acid (PAA) is another oxidizing agent, which results from the combination of peracetic acid and hydrogen peroxide. It is well-known as an environmentally friendly product as well as tolerant to $\mathrm{pH}$, temperature and organic load [53]. PAA exerts its antimicrobial action through the production of reactive oxygen species that damage DNA and lipids. It can also denature proteins and affect the cell wall [54]. However, it has been reported that concentrations higher than those allowed $(80 \mathrm{ppm})$ are necessary to achieve significant microbial reductions in fruits and vegetables-a distinct disadvantage [33].

Table A2 presents investigations that mainly demonstrate the efficacy of PAA against pathogens artificially inoculated in blueberries. For instance, Singh et al. [55] found that the application of PAA at $45 \mathrm{mg} / \mathrm{L}$ for $5 \mathrm{~min}$ achieved a reduction of $5.7 \mathrm{log}$ CFU/g of E. coli O157:H7 in blueberries. Along these lines, the effect of PAA was comparable with other disinfectants such as chlorine-based sanitizers (acidic electrolyzed water, near-neutral electrolyzed water, and bleach) and lactic acid. In the case of Salmonella, the greatest reduction $(6.4 \mathrm{log}$ CFU/g) was achieved by the application of $2 \%$ lactic acid, followed by PAA at 45 and $100 \mathrm{mg} / \mathrm{L}$, which resulted in the same reduction (5.9 log CFU/g). Experimental results on wash water demonstrated the elimination of pathogens by the application of both lactic acid and various PAA treatments, a very important finding for avoiding cross-contamination of products during the disinfection process [55].

In another study, Sheng et al. [56] demonstrated that the application of $0.4 \%$ Neo-Pure (PAA at $450 \mathrm{ppm}$ ) together with cold storage was more efficient in reducing L. monocytogenes compared to chlorine (100 ppm) (Table A2). In the study of Callahan et al. [57], in a custom-built pilot-scale processing line and setup for treatment of inoculated wild blueberries, L. innocua was reduced by $2.2 \log \mathrm{CFU} / \mathrm{g}$ after immersion and spraying with PAA $(80 \mathrm{ppm}, 3 \mathrm{~min})$. Furthermore, the importance of the inoculation method is highlighted, revealing that $L$. monocytogenes dip-inoculated on blueberries was more difficult to eradicate by both disinfectants than the spot-inoculated product [56].

Regarding the antimicrobial effect on the native flora, Sheng et al. [56] found that the use of Neo-Pure $(2 \mathrm{~min})$ followed by cold storage $\left(4{ }^{\circ} \mathrm{C}\right.$ and $\left.-15^{\circ} \mathrm{C}\right)$ allowed the total plate count (TPC) to remain stable, with the exception of YMC at $4{ }^{\circ} \mathrm{C}$, which increased up to $\sim 4.6 \log \mathrm{CFU} / \mathrm{g}$ after 14 days of storage. On the other hand, a treatment of 3 min combining immersion in PAA ( $80 \mathrm{ppm})$ followed by spraying with chlorine $(200 \mathrm{ppm})$ had limited success in reducing the yeast population $(<1.0 \log \mathrm{CFU} / \mathrm{g})[57]$.

PAA is presented as a good alternative to chlorine for microbial decontamination of blueberries destined for the fresh and frozen market. However, more studies are required to design novel formulations based on combined strategies since the effect of PAA seems to be reduced against moulds according to recent studies. It would also be important to learn more about the subsequent microbial behaviour as well as the sensory and physicochemical parameters of blueberries during storage.

\subsection{Hydrogen Peroxide and Organic Acids}

Hydrogen peroxide $\left(\mathrm{H}_{2} \mathrm{O}_{2}\right)$ and organic acids are presented as alternative means for protecting blueberries from deterioration and ensuring their safety. $\mathrm{H}_{2} \mathrm{O}_{2}$ is a strong oxidant that forms cytotoxic species that damage the proteins and DNA of microorganisms. It can be used both in aqueous and gaseous form at concentrations between 1-5\% [45]; however, its use in fruits can be limited since the 
use of high concentrations could produce the oxidation of anthocyanins, changes in colour, and a decrease in antioxidant properties [33,58].

In contrast, the few studies reported on the use of $\mathrm{H}_{2} \mathrm{O}_{2}$ have shown its efficacy as a blueberry sanitizer without adversely impacting their quality. For example, blueberries treated with vapor phase $\mathrm{H}_{2} \mathrm{O}_{2}\left(60 \mathrm{~min}\right.$, up to $214 \mathrm{ppm}$ of $\mathrm{H}_{2} \mathrm{O}_{2}$ ) exhibited an inactivation of murine norovirus (MNV) of $4 \log \mathrm{PFU} / \mathrm{mL}$. The treatment did not cause changes in the colour or consistency of the fruits [59]. Despite these studies, it would be advisable to examine more closely the organoleptic and nutritional aspects to obtain a better understanding of the actual efficiency of $\mathrm{H}_{2} \mathrm{O}_{2}$ for disinfection of blueberries.

On the other hand, the antimicrobial action of organic acids is due to the reduction of the environmental and cellular $\mathrm{pH}$ of microorganisms [60]. The main disadvantage of these treatments is the requirement of long exposure times ( $>5 \mathrm{~min}$ ) to reduce the microbial load, which may affect the organoleptic characteristics of the products [29].

The use of single and combined washing methods of $\mathrm{H}_{2} \mathrm{O}_{2}$, organic acids (lactic acid, acetic acid and citric acid), and SDS has been applied for the reduction of Salmonella in blueberries [61]. The best treatments that achieved reductions $\geq 4.0 \log$ CFU/g with an exposure time of 5 min were $0.5 \mathrm{mg} / \mathrm{mL}$ acetic acid plus 5000 ppm SDS, and 200 ppm $\mathrm{H}_{2} \mathrm{O}_{2}$ plus 5000 ppm SDS. These treatments showed equivalent reductions to $200 \mathrm{ppm}$ of chlorine, and apart from the texture, they did not affect the colour, total phenolic $(78.34$ and $80.68 \mathrm{mg} / 100 \mathrm{~g})$ and anthocyanin $(0.324$ and $0.308 \mathrm{mg} / \mathrm{g})$ concentrations. In addition, the selected treatments kept the pathogen populations constant in blueberries and decreased the YMC during storage for 3 days at $4{ }^{\circ} \mathrm{C}$.

On the other hand, due to the high redox potential, low $\mathrm{pH}$ and high concentration of dissolved active oxygen, electro-activated solutions of organic acid salts have been evaluated for microbial decontamination of blueberries [62]. These solutions, unlike electrolyzed $\mathrm{NaCl}$ solutions, have the advantage of not generating toxic chlorine. In this sense, electro-activated potassium acetate solution achieved significant reductions of moulds and pathogenic bacteria (Table A2). Likewise, in the same study [62], it was observed that the application of the solutions-potassium acetate, potassium citrate and calcium lactate-for $1 \mathrm{~min}$, and subsequent storage at $2{ }^{\circ} \mathrm{C}$ for six weeks did not adversely affect the colour or texture of blueberries. Taking into account the advantages offered by electro-activated solutions of organic acid salts, it would be interesting to evaluate their potential in the inactivation of other pathogens such as viruses and parasites. Additionally, further evaluations on the effect of these on the bioactive compounds and organoleptic characteristics of blueberries at different concentrations and exposure times, would be of high interest.

\subsection{Edible Coatings}

The application of edible coatings has shown great potential in preserving the quality of fresh blueberries [63,64]. Edible coatings can contribute to the control of moisture transfer, gas exchange, and oxidation processes in fruits [65]. Edible coatings can be made of proteins, polysaccharides, and lipids. Among these materials, polysaccharides such as chitosan, alginate, carrageenan, and agar have been widely studied for the development of edible coatings. These coatings can also be used as carriers of different substances such as antimicrobials, nutraceuticals, and antioxidants. Table A2 summarizes different studies that evaluate the effect of these edible coatings alone or in combination with other functional substances in quality and safety of fresh blueberries.

Coatings made of chitosan have been extensively evaluated in blueberries. Chitosan, derived from the chitin polymer, is a good film former with a broad antimicrobial activity and compatibility with other substances [66]. Its antimicrobial action mechanisms include the alteration of cell permeability, interference with the synthesis of proteins, and the quelation of nutrients and oxygen for cells $[67,68]$. However, as disadvantage, it has been reported that chitosan has weak mechanical properties and limited barriers to water vapor [69]. Chitosan has shown better antifungal activity than coatings with sodium alginate. However, blueberries coated with sodium alginate have shown better firmness and lightness after 45 days of storage at $0{ }^{\circ} \mathrm{C}[63,70]$. Jiang et al. [71] demonstrated that blueberries coated 
with $6 \mathrm{mg} / \mathrm{mL}$ chitosan showed better quality parameters after 35 days of storage at $2{ }^{\circ} \mathrm{C}$ compared to the control samples; the berries treated with low molecular weight chitosan showed a firmness of $159.1 \mathrm{~g}$, while the control had a value of $117.0 \mathrm{~g}$ at the end of storage. Likewise, the total phenolic and anthocyanin values were 417.0 and $178.1 \mathrm{mg}$ per $100 \mathrm{~g}$ of fresh weight, respectively, in the blueberries treated, and 382.8 and $141.3 \mathrm{mg}$ per $100 \mathrm{~g}$, respectively, in the control samples.

Other coatings have been used to increase the antimicrobial effect of chitosan and to extend the shelf-life of blueberries. Sun et al. [72] found that the incorporation of trans-cinnamaldehyde essential oil at a concentration of $0.5 \%$ to the chitosan coating provided an improved protective effect against softening and decreased the microbial population of blueberries after storage at $10{ }^{\circ} \mathrm{C}$ for 7 days, compared to the untreated berries and those coated with chitosan alone. Coatings made of a mixture of quinoa protein, chitosan, and sunflower oil delayed the ripening of blueberries and controlled mould growth for 32 days at $4{ }^{\circ} \mathrm{C}$. However, the firmness and colour of the fruit were affected by the coating [73]. Another study used a coating based on chitosan, glycerol, Tween 80, and Aloe vera extract, which controlled fungal deterioration and prolonged the shelf-life of blueberries for 5 days [74]. Alvarez et al. [75] found that the addition of oligofructose and orange fibre to chitosan coatings increased the antifungal effect. Similarly, chitosan coatings enriched with inulin, oligofructose, and apple fibre extended the shelf-life of blueberries for 6 days. Yang et al. [76] showed a delay in decomposition and water loss in blueberries coated with chitosan plus $12 \%$ blueberry leaf extract during storage in a modified atmosphere $\left(3 \mathrm{kPa} \mathrm{O}_{2}+12 \mathrm{kPa} \mathrm{CO}_{2}\right)$ at $2{ }^{\circ} \mathrm{C}$, while total phenolic content and radical scavenging activity were preserved during storage.

In recent years, research efforts have been directed to the development and evaluation of coatings based on marine polysaccharides with antiviral potential. In this sense, coatings made of carrageenan and tea extract reduced the infectivity of MNV by more than $3.5 \log$ in fresh blueberries kept at ambient temperature and between 2.4 and $3.1 \mathrm{log}$ under refrigeration conditions. In the case of HAV, the effect of these coatings was more accentuated at $25^{\circ} \mathrm{C}$ with reductions between $1.8-2.8 \mathrm{log}$. The coatings preserved the firmness and appearance of the blueberries [77]. On the other hand, the addition of Larrea nitida extract to the alginate/agar coating had a synergistic effect on the reduction of MNV in blueberries stored at $10{ }^{\circ} \mathrm{C}$ [78]. The above findings are an important basis for the development and optimization of formulations with the addition of other substances that allow-in addition to the reduction of pathogens-the deterioration caused by moulds to be minimized. Additionally, it would be pertinent to evaluate physicochemical parameters in blueberries during storage conditions.

Finally, liposomes as nano-carriers are presented as an alternative to obtaining an improved delivery of antimicrobial substances. In this sense, liposomes with $50 \mu \mathrm{M}$ limonene reduced mould deterioration in blueberries by more than $60 \%$ at the end of nine weeks of storage at $4{ }^{\circ} \mathrm{C}$ [79].

All in all, edible coatings technology in combination with other substances is a natural alternative for preserving the quality and safety of fresh blueberries while providing an added value to the final product. However, the cost of materials, the loss of waxy bloom in the blueberries, and the difficulties encountered in the coating operations are current limitations to bear in mind. Furthermore, the effect of coatings should be evaluated in the different cultivars to avoid quality defects. The incorporation of nanotechnology in the application of antimicrobial components currently constitutes a promising alternative for further research.

\section{Physical Strategies}

Physical technologies are those achieving microbial decontamination through physical means, without the addition of chemical sanitizers or biopreservatives. However, many of these technologies are used in combination with other chemical methods, to increase their antimicrobial efficiency and better preserve the quality of food products.

Classically, there is a distinction between thermal and non-thermal technologies. Thermal technologies are based on the application of heating regimes for microbial decontamination of fruits and vegetables that are to be processed in the industry. However, they are not suitable for disinfection of fruits and 
vegetables intended to be consumed as fresh due to the degradation of their organoleptic characteristics. Instead, non-thermal technologies are widely used since they do not affect to any great extent the organoleptic and structural properties of fruits and vegetables with a minimal loss of heat-sensitive bioactive compounds [26,80].

Since most published studies of physical decontamination of blueberries rely on the use of non-thermal technologies, this section will describe the evaluation and optimization of such technologies for their use in blueberries and derived products (Table A3).

\subsection{Ultraviolet Light}

Ultraviolet (UV) light is an electromagnetic radiation with wavelengths between 100 and $400 \mathrm{~nm}$ [27]. According to the spectrum, it is classified as UV-A (315-400 nm), UV-B (280-315 nm), UV-C (200-280 nm), and vacuum UV (100-200 nm) [81]. It has been reported that UV-C has the highest antimicrobial effect; at $254 \mathrm{~nm}$ it inhibits the DNA synthesis of microorganisms, which leads to their inactivation [82].

However, application of UV-C alone does not achieve a substantial microbial reduction on berries. This is because microbial decontamination of fresh products by this technology is limited due to its low penetration capacity, sample heating, and shading effect [83]. Furthermore, at low UV doses, injured cells can be gradually recovered during storage. As regards the effect of UV on sensory quality, several studies have found no significant changes in the colour or texture of blueberries [84-86].

To overcome the abovementioned limitations of this technology, different alternatives have been proposed. One of them is the use of water-assisted UV systems (WUV). Among the advantages of these systems are the more uniform exposure of products to UV light, the synergistic action between UV and other chemical disinfectants added to water, and the inactivation of microorganisms in water once the products are washed [83]. Regarding this, several investigations have shown greater efficacy for blueberry decontamination in WUV compared to dry UV (Table A3). As an example, on a small scale with exposure times of $2 \mathrm{~min} W U V$, treated blueberries showed a great reduction of MNV-1 ( $>4.2 \log$ PFU/sample) compared to dry UV treatment (2.5 log PFU/sample) [83]. Additionally, the treatment was comparable to washing in $10 \mathrm{ppm}$ chlorine for $2 \mathrm{~min}$ ( $>4.6 \log$ PFU/sample). In the same study, the combination of WUV plus $10 \mathrm{ppm}$ chlorine in a large-scale experiment had an enhanced inactivation compared to the independent technologies. This work also highlighted the difficulty of using UV in eliminating microorganisms present on rough surfaces such as the blueberry calyx, in which the reductions after all treatments were $<2 \log$ PFU/sample [83]. This result confirms what other researchers have reported - a greater reduction of pathogens on the skin than on the blueberry calyx after application of UV together with chemical methods [52,86,87]. On the other hand, Huang et al. [88] proposed WUV $\left(23-28 \mathrm{~mW} / \mathrm{cm}^{2}\right)$ combined with PAA ( $\left.80 \mathrm{ppm}\right)$ for $2 \mathrm{~min}$ as recommended treatment for fresh blueberries due to its great efficiency in reducing Salmonella in water with elevated turbidity conditions. It is also noteworthy that the treatment achieved residual Salmonella cells in wash water below the detection limit. However, none of the treatments were able to eliminate Salmonella in the assayed berries completely.

Finally, photocatalysis technology has been studied as an alternative to overcome the limitations of UV light $[89,90]$. The microbial inactivation by $\mathrm{UV}-\mathrm{TiO}_{2}$ photocatalysis is due to the production of hydroxyl radicals that are generated when the $\mathrm{TiO}_{2}$ is illuminated with UV light at wavelengths $<385 \mathrm{~nm}$ [91]. In this sense, $\mathrm{UV}-\mathrm{TiO}_{2}$ photocatalysis $\left(4.5 \mathrm{~mW} / \mathrm{cm}^{2}\right)$ for $30 \mathrm{~s}$ achieved higher bacterial reductions (5.3 log CFU/g) on blueberry skin than applying $\mathrm{UV}$ alone at $6.0 \mathrm{~mW} / \mathrm{cm}^{2}(4.5 \mathrm{log} \mathrm{CFU} / \mathrm{g})$. Both treatments increased the total phenol and anthocyanin content [91]. This study is in line with other findings showing the accumulation of bioactive compounds after exposure to UV light, which indicate a defence response of the fruits to the stress generated by the irradiation $[92,93]$.

Thus, the use of UV light is conditional upon its combination with other disinfection technologies given its relatively low efficiency, especially when dealing with irregular shaped fruits, or in the presence of high organic material in water-assisted treatments. 


\subsection{Pulsed Light}

Pulsed light (PL) is a physical technology where the inactivation of microorganisms is achieved using short time-high intensity light pulses. PL includes a wide wavelength range from UV to near infrared (200-1100 nm) [94]. Fluence is considered one of the most important factors in PL treatments [95]. A fluence level up to $12 \mathrm{~J} / \mathrm{cm}^{2}$ is allowed for food applications [96]. Likewise, factors such as the distance from the light source to the sample or the food characteristics also influence the efficiency of the treatment $[94,95]$. One of the main benefits of PL is the achievement of significant microbial reductions in short exposure times [94]. In blueberries, a treatment of PL for $12 \mathrm{~s}$ at a fluence of $11.4 \mathrm{~J} / \mathrm{cm}^{2}$ achieved log reductions of MNV-1, Salmonella and E. coli O157:H7 of 3.2, 3.8 and 5.6, respectively [97]. It has been reported that PL has a greater antimicrobial effect than UV light [35]. Nevertheless, implementation of PL equipment is more expensive than UV light and application of high fluences can also lead to deterioration of quality attributes due to the increase of product temperature [23,35]. It should also be noted that-similar to UV—PL treatments have limitations such as a low penetration in solid foods or a non-uniform exposure, among others.

To solve these inconveniences, several investigations have been focused on the use of wet PL (WPL) for microbial decontamination of blueberries and other derived products [23,98,99]. Huang et al. [23] demonstrated that dry PL for $60 \mathrm{~s}$ caused discoloration in blueberries which was related to the increase of temperature of the samples; in contrast, the WPL treatment helped to mitigate the heating effect while preserving the sensory quality of blueberries. Although the application of WPL showed a good performance against bacterial pathogens, YMC were lightly reduced, i.e., less than 1 log CFU/g.

Some authors [98] have studied the effect of WPL, showing, as expected, lower levels of Salmonella and YMC than untreated samples after storage at room temperature for 3 days and at $5{ }^{\circ} \mathrm{C}$ for 7 days. In addition, when comparing with dry PL $\left(6 \mathrm{~J} / \mathrm{cm}^{2}\right)$ for $30 \mathrm{~s}$ and washing water, WPL $\left(9 \mathrm{~J} / \mathrm{cm}^{2}\right)$ for $45 \mathrm{~s}$ was more efficient in the microbial decontamination of blueberries. In terms of quality, WPL seemed not to produce substantial changes in the decontaminated product, finding that WPL did not affect the total phenolic content and minimally impacted the colour of blueberries. In contrast, anthocyanin content and antioxidant activity were slightly lower in WPL compared to dry PL. At room temperature, the authors noted the undesired presence of leaks in blueberries treated with water and WPL, limiting the use of water for subsequent non-refrigerated storage.

Other studies evaluating the use of UV and PL technologies have shown that they can be equally effective against pathogenic bacteria when comparing the performance between WUV and WPL [100]. The studies found that there were no significant differences in the reduction of Salmonella in blueberries. Despite the advantages of the water-assisted system, the residual moisture resulting from the process can favour the deterioration of blueberries for which it is advisable to apply drying to reduce alteration during storage.

Concerning PL technology, future efforts should be focused on improving the processing conditions and obtaining more economical equipment for its implementation on an industrial scale.

\subsection{High Hydrostatic Pressure}

High hydrostatic pressure (HHP) is a consolidated non-thermal technology in which food is generally exposed to pressures of 300-600 MPa conveyed by water. High pressure causes microbial death due to the destruction of the cell membrane and wall, and also affects proteins [80]. The antimicrobial effect of this method depends on factors such as temperature, $\mathrm{pH}$, treatment time, product characteristics, and pressure resistance of microorganisms [101].

Published studies on blueberries showed that human norovirus and its surrogates were more sensitive to pressure in wet than in dry blueberries, and the effectiveness of HHP inactivation increased when the sample temperature decreased (Table A3). Other authors found that a treatment of $550 \mathrm{MPa}$ for $2 \mathrm{~min}$ at $0{ }^{\circ} \mathrm{C}$ achieved a satisfactory inactivation of HuNoV GI.1 and GII.4 on fresh blueberries and in puree [102]. Furthermore, the quality attributes of the puree (general appearance, viscosity, aroma, colour, and general acceptability) were not adversely affected by the treatment, in contrast with 
the textural modifications induced by HHP in fresh fruits. As regards textural modifications, other researchers showed that blueberries were softened during pressurization and concluded that HHP intended for fresh blueberries was inadequate $[103,104]$.

The synergy of natural antimicrobials and HHP is presented as another alternative to increase the efficiency of this technology. In this regard, Kabir et al. [105] evaluated the addition of carvacrol and caprylic acid for the inactivation of serogroups O157 and non-STEC Escherichia coli in blueberry juice. As an example, while at $450 \mathrm{MPa}$ and $4{ }^{\circ} \mathrm{C}$, the D-value for non-STEC was $8.03 \mathrm{~min}$, when $0.5 \%$ carvacrol was added, the D-value was reduced to $2.92 \mathrm{~min}$ [105]. Additional factors such as pathogen adaptation to food matrix or selection of strains according to their pressure resistance should be considered when evaluating the efficiency of this technology.

It can be concluded that HHP constitutes an effective technology mainly for the treatment of blueberry derivatives with minimal effects on quality.

\subsection{Pulsed Electric Field}

Pulsed electric field (PEF) is a technology based on the application of electric pulses of short duration $(\mu \mathrm{s})$ and high voltage $(20-80 \mathrm{kV} / \mathrm{cm})$ to foods placed between two electrodes [106]. This process produces a rupture of the cell membrane, and thus the inactivation of microorganisms [107]. Among the factors that determine the lethal effect of PEF are electric field strength, treatment time, pulse shape, and start temperature. Similarly, the nature of microorganisms and product parameters such as composition, $\mathrm{pH}$, or conductivity, among others, are also considered as factors influencing the extent of microbial inactivation by PEF [108]. However, limitations of this technology are its high cost and technical difficulties in setting the parameters' targets [109].

The use of combined strategies using PEF and other disinfectants is reported in the literature. The combination of PEF plus PAA $(0.25 \%)$ for 4 min allowed efficient decontamination of blueberries compared to the use of PEF alone $(2 \mathrm{kV} / \mathrm{cm})$. As an example, E. coli was reduced by less than $0.5 \log \mathrm{CFU} / \mathrm{g}$ with the PEF treatment, while the combined treatment achieved up to $2.9 \log \mathrm{CFU} / \mathrm{g}$ reduction [110]. In that study, long treatment times were used to compensate for low field strength. Although the combined treatment preserved the colour and increased the concentration of anthocyanins and phenolic compounds by $10 \%$ and $25 \%$, respectively, the texture of the fruit was damaged, indicating that the treatment is not recommended for fresh blueberries.

In liquid matrices, Chen et al. [111] evidenced an increase in the inactivation of $E$. coli in blueberry juice by increasing the electric field and processing time. In this sense, the treatment at $35 \mathrm{kV} / \mathrm{cm}$ and $82 \mu$ s reduced the pathogen by $5.12 \log \mathrm{CFU} / \mathrm{mL}$. Regarding the quality of the juice, PEF treatment at $30 \mathrm{kV} / \mathrm{cm}, 54 \mu \mathrm{s}$, and $1.4 \mathrm{~ms} / \mathrm{cm}$ maintained colour, aroma, and greater retention of vitamin $\mathrm{C}$ and anthocyanins after storage at $4{ }^{\circ} \mathrm{C}$ for 30 days compared to heat treatment while achieving commercial sterility. Other parameters such as acidity and phenol content changed slightly after treatment [111].

In order to overcome the cost and to control the settings of parameters of the PEF equipment, microchips have been designed and improved for low-voltage PEF sterilization [109]. This technology has shown great potential in microbial inactivation while preserving the quality of juice. For example, treatment with microchip-PEF at $400 \mathrm{~V}$ and $0.2 \mathrm{~ms}$ efficiently inactivated spoilage microorganisms in blueberry juice [112]. Likewise, blueberry juice treated with microchip-PEF ( $350 \mathrm{~V}, 0.15 \mathrm{~ms}, 7 \mathrm{~mL} / \mathrm{min})$ was microbiologically stable and preserved its colour and nutritional properties after storage for 30 days at $4{ }^{\circ} \mathrm{C}$ [113].

In the light of the published studies, PEF seems to be a valid alternative for microbial disinfection of derived blueberry products being able to preserve most of the quality parameters. However, its use on fresh blueberries should be optimized because of damage to the texture of the blueberries.

\subsection{Cold Plasma}

Cold plasma (CP) is a novel non-thermal technology based on the use of ionized gases [33]. CP is generated from air or other feed gases by different energy sources [114]. The microbial inactivation by 
this technology is achieved by UV light and reactive chemical products derived from the ionization process [114]. However, it has been reported that this technology could produce some undesirable organoleptic changes in blueberries, such as a reduction of firmness and anthocyanin content and changes in colour parameters [115].

$\mathrm{CP}$ has been studied by different researchers for disinfection of blueberries, as shown in Table A3. Though optimization of this technology is required for its use in blueberries, it was shown to be effective in reducing microbial contamination of norovirus surrogates, as demonstrated by Lacombe et al. [116]. In relation to the native microbiota, $\mathrm{CP}$ has been shown to be more effective in the inactivation of bacteria than fungi $[115,117,118]$. In this way, Pathak et al. [118] recommended nitrogen-generated CP treatments greater than $5 \mathrm{~min}$ for effective reduction of moulds and yeasts.

In relation to the effect of $\mathrm{CP}$ on the sensory and nutritional aspects of blueberries, the different findings can be attributed to the different treatment conditions. Lacombe et al. [115] associated the reduction of firmness and anthocyanin content in blueberries treated with air-generated CP (air plasma jet, $47 \mathrm{kHz}$ and power consumption of $549 \mathrm{~W}$ ) to the increase in temperature and the presence of ozone and other free radicals. Softening of the fruits was also attributed to mechanical damage during the process. Similarly, the colour was significantly affected after $120 \mathrm{~s}$ for $L^{*}$ and $a *$ values, and $45 \mathrm{~s}$ for $b *$ In this sense, blueberries became darker and with an increase of the perceived surface red and blue colours. On the contrary, Dong et al. [117] reported an increase in the contents of sugar, vitamin C, and total anthocyanin in blueberries treated with air-generated CP (dielectric barrier discharge with $19.7 \mathrm{kHz}$, and 6.48-W input power consumption) and stored for 20 days in comparison with control samples. Pathak et al. [118] did not find significant differences regarding the content of ascorbic acid, anthocyanins, solids, and titratable acidity in blueberries treated with N-generated CP (diffuse coplanar surface barrier discharge, $300 \mathrm{~V}$ ) and stored for 10 days at $7{ }^{\circ} \mathrm{C}$ with respect to control fruits. However, the authors recommended treatments of less than $10 \mathrm{~min}$ to avoid significant changes in texture.

Regarding the application in blueberry juice, Hou et al. [119] found that the application of CP achieved an increase in the content of phenolics and preserved the original colour compared to the heat treatment. In contrast, treatment times of less than 4 min were suggested to maintain the anthocyanin content and vitamin $C$ in the samples.

In comparison with other strategies, high antimicrobial activity of $\mathrm{CP}$ against $B$. cinerea was demonstrated by Zhou et al. [120] on blueberries versus the use of aqueous ozone after storage at $20^{\circ} \mathrm{C}$ for 8 days. The blueberries treated with $\mathrm{CP}$ showed a high firmness and ascorbic acid concentration.

In summary, $\mathrm{CP}$ is a technology with great potential for microbial decontamination of blueberries. However, the optimization and standardization of process parameters (power, plasma source, setup, and treatment time) are necessary. In addition, further inactivation studies evaluating the effect of technology on microbial fate and product quality under different storage conditions is required.

\subsection{Ionizing Irradiation}

Ionizing irradiation, such as X-rays, gamma rays and electron beams act on water molecules forming free radicals that inactivate microorganisms [33]. However, softening and quality loss of fruits treated at high doses is one of the limitations of this technology [121]. The FDA restricts the maximum level of irradiation of fresh fruits and vegetables to $1.0 \mathrm{kGy}$ [122].

The antimicrobial effect and preservation of quality attributes after an irradiation treatment in blueberries can differ according to published studies. Doses of gamma irradiation of $0.4 \mathrm{kGy}$ had a limited effect on the population of moulds and yeasts and pathogenic bacteria in blueberries during storage at $0-1{ }^{\circ} \mathrm{C}$ for 31 days [123], being $11 \%$ softer than control samples, while soluble solids content, titratable acidity, and weight loss were not affected by the treatment. However, other authors [124] found that Toxoplasma gondii oocysts were reduced by $4 \log$ PFU/g at low doses of gamma irradiation $\left(0.2,0.4\right.$ and $0.6 \mathrm{kGy}$ at $\left.4{ }^{\circ} \mathrm{C}\right)$ without affecting firmness, anthocyanins, and colour in blueberries. Shelf-life studies should be performed to evaluate the effect of processing parameters during the storage period. 
Regarding the nature of rays, although the electron beam has less penetration ability compared to gamma rays, electron beam irradiators have the advantage of being electronic in nature, meaning a potential alternative as safety concerns are not comparable to cobalt-60 concerns, the latter being implicated in gamma rays technology. Likewise, electron beam irradiation allows the use of high doses with great precision [125-127]. Kong et al. [125] showed that electron beam irradiation at low doses $(<3 \mathrm{kGy})$ extended the shelf-life of blueberries without affecting their antioxidant activity, total monomeric anthocyanin, and L-ascorbic acid content. The same study found a $\mathrm{D}_{10}$ value average for E. coli K-12 of $0.37 \mathrm{kGy}$ on blueberries. On the other hand, Nambeesan et al. [127] reported that blueberry cultivars treated with doses of $1.0 \mathrm{kGy}$ showed reductions of $\leq 1 \mathrm{log}$ for the total of aerobic bacteria and yeasts after 6 days at $2-4{ }^{\circ} \mathrm{C}$. In the case of coliforms, the reductions were $<1 \log$ for the "Farthing" cultivar and 2 log units for "Rebel". Likewise, the authors did not find any significant effect of irradiation on the incidence of post-harvest diseases, concluding that higher doses would be required for the elimination of plant-pathogenic fungi in blueberries. The firmness was only reduced in the "Farthing" cultivar. Other parameters such as soluble solids content or titratable acidity were not affected.

All in all, at the permitted doses, irradiation helps to reduce the microbial load but does not guarantee neither the safety of blueberries nor spoilage control. The combination of irradiation with other technologies could be considered in future investigations to achieve greater efficiency for the disinfection of fresh blueberries.

\subsection{Ultrasound}

Ultrasound (US) is considered another technology useful for the treatment of fruit and derivatives. The antimicrobial effect of US is attributed to cavitation and the formation of free radicals which alter the cell wall and membrane producing damage in DNA structure [127]. The efficiency of this method depends on several factors including wave frequency, power, and exposure time [128]. Likewise, this technology needs to be accompanied by other chemical or physical strategies due to its limited antimicrobial effect $[33,35]$.

To increase the efficiency of US, it can be used together with pressure treatment (manosonication), heat treatment (thermosonication), or both (manothermosonication). In this sense, moulds and yeasts were completely inactivated in nectar and blueberry juice with high power ultrasound $(20 \mathrm{kHz})$ in combination with heat $\left(60^{\circ} \mathrm{C}\right)$ and treatment times of 3-9 $\min$ [129]. Zhu et al. [130] found that manothermosonication $\left(560 \mathrm{~W}, 40^{\circ} \mathrm{C} / 350 \mathrm{MPa}, 40^{\circ} \mathrm{C}\right.$ ) achieved a rapid inactivation of E. coli O157:H7 in blueberry juice after $5 \mathrm{~min}$, while $97.49 \%$ of anthocyanin content was retained and the polyphenol oxidase activity decreased to $10.91 \%$. In relation to the treatment of fresh products, the combination of US with natural chemicals has been explored as an alternative to improve the safety and efficacy of sanitation processes (Table A3). However, the long treatment times make its industrial application unfeasible. More studies are required to up-scale this technology [131].

\section{Biological Strategies}

Finally, biological methods are considered as a promising alternative to improve the quality and safety of fresh fruits [33]. Treatments based on the use of bacteriophages, lactic bacteria, metabolites of microorganisms, and other compounds of biological origin have been tested for the reduction of pathogen and spoilage in vegetables [27,132]. Moreover, in recent years, several studies have evaluated biological strategies as alternatives to chemical and physical methods for microbial decontamination of blueberries. For example, washing with $1 \%$ denatured lysozyme for 1 min was comparable to washing with $100 \mathrm{ppm}$ chlorine, and it showed reductions of HAV and MNV-1 of $3.9 \log \mathrm{MNP} / \mathrm{g}$ and $4.2 \log$ PFU/g, respectively, in fresh blueberries [133]. Likewise, Bambace et al. [134] evaluated the application of alginate coatings with the addition of fructo-oligosaccharides and probiotic lactobacilli in fresh blueberries. The coating was able to inhibit L. innocua counts by 1.7 log and the firmness and sensory acceptability of blueberries was unaffected for 14 days in refrigeration, time after which 
the highest rate of fungal decay was observed (60\% at 21 days). On the other hand, the inclusion of cyclolipopeptides produced by Bacillus subtilis to alginate coatings decreased respiration and fungal contamination in blueberries stored at -1 to $0{ }^{\circ} \mathrm{C}$ for 20 days [135]. On the other hand, the use of different biological compounds such as vegetable extracts and essential oils has been widely evaluated in blueberries (Section 3.5). The use of pullulan coatings, an exopolysaccharide produced by the fungus Aureobasidium pullulans, combined with propolis extract reduced the population of bacteria and moulds by $3-4.5 \log$ in fresh blueberries stored at $16{ }^{\circ} \mathrm{C}$ for 21 days. In addition, these coatings contributed to the delay in the ripening of blueberries and the decrease in water loss [136]. The application of allyl isothiocyanate, a natural compound present in plants of the Cruciferae family, reduced blueberry decomposition during storage at $10^{\circ} \mathrm{C}$ for 21 days, which was associated with the generation of reactive oxygen species. However, the contents of total phenolics, anthocyanins, and antioxidant capacity of blueberries decreased [19]. Finally, the use of hexanal, a natural plant volatile, has shown antifungal properties in blueberries. In this sense, three applications of $900 \mathrm{ppm}$ of hexanal vapor for $24 \mathrm{~h}$ at $0.5^{\circ} \mathrm{C}$ combined with controlled atmosphere storage (10-12 $\mathrm{kPa} \mathrm{O}_{2}$ and $\left.12-15 \mathrm{kPa} \mathrm{CO}_{2}\right)$, allowed for a lesser decay and longer shelf-life after 15 weeks of storage at $0.5^{\circ} \mathrm{C}$ [137].

Biological strategies constitute a natural alternative to promote the safety and quality of blueberries destined for the fresh market, although not enough studies have yet been conducted. The development of blueberries with multifunctional properties (e.g. probiotics-added blueberries) is an important research line where substantial efforts should be invested.

\section{Conclusions}

In the last decades, different chemical and physical strategies have been evaluated for microbial decontamination of blueberries. It is only recently that biological methods have been tested. However, there are future perspectives for this kind of applications in blueberries. Several of these strategies showed comparable results and were even superior to traditional disinfection methods, and in addition, they greatly overcame side effects observed with the use of classical disinfectants such as chlorine.

To summarise, according to the studies reviewed, $\mathrm{PL}$ and $\mathrm{CP}$ technologies show promising results for use in blueberry decontamination. Among the chemical strategies, PAA, EOW, and aqueous ozone have great potential to replace chlorine for the elimination of microorganisms on the surface of blueberries. Gaseous chlorine dioxide and edible coatings are advantageous for blueberries intended for the fresh market. In relation to derived products such as blueberry puree or juice, technologies such as HHP and PEF achieve satisfactory microbial inactivation with minimal impact on the sensory and nutritional quality of the products. Likewise, it is a common observation that the use of combined technologies by application of the well-known "hurdle technology" offers greater antimicrobial effectiveness while preserving the quality of the products [80]. Further studies should evaluate the potential of technologies against microbial adhesion on the surface of blueberries since most of the published studies have carried out disinfection treatments within a few hours after inoculation. Future inactivation studies should also cover a broader range of pathogens such as viruses or parasites, including the effect of variability between strains.

Finally, research efforts should be focused on the effect of these strategies on microbial inactivation as well as on the sensory and nutritional quality of blueberries, especially during their shelf-life. It is only with this approach that an integral evaluation of these technologies can be performed.

Author Contributions: L.P.-L., conceptualization and writing. E.C. and A.V., revision, editing, and funding acquisition. All authors have read and agreed to the published version of the manuscript.

Funding: This research was funded by the Spanish Government (Ministry of Economy and Competitiveness, research project AGL2016-78086-R), Agrifood International Campus of Excellence (ceiA3) (Spain), Universidad Simón Bolívar (Colombia) and Asociación Universitaria Iberoamericana de Postgrado (Scholarship to L.P.L.).

Acknowledgments: The authors are grateful to the Spanish Government (Ministry of Economy and Competitiveness, research project AGL2016-78086-R), to the “Asociación Universitaria Iberoamericana de Postgrado (AUIP)" for their financial support for L.P.L.; to the Agrifood International Campus of Excellence (ceiA3) (Spain) and to the Universidad Simón Bolívar (Colombia). 
Conflicts of Interest: The authors declare no conflict of interest.

\section{Abbreviations}

$\begin{array}{ll}\text { CFU } & \text { colony-forming units } \\ \text { COD } & \text { chemical oxygen demand } \\ \text { CP } & \text { cold plasma } \\ \text { EOW } & \text { electrolyzed oxidizing water } \\ \text { FCV } & \text { feline calcivirus } \\ \text { FDA } & \text { Food and Drug Administration } \\ \text { HAV } & \text { hepatitis A virus } \\ \text { HHP } & \text { high hydrostatic pressure } \\ \text { HuNoV } & \text { human norovirus } \\ \text { MNV } & \text { murine norovirus } \\ \text { MS } & \text { manosonication } \\ \text { MT } & \text { manothermal } \\ \text { MTS } & \text { manothermosonication } \\ \text { NTU } & \text { nephelometric turbidity unit } \\ \text { PAA } & \text { peracetic acid } \\ \text { PEF } & \text { pulsed electric field } \\ \text { PFU } & \text { plaque forming units } \\ \text { PL } & \text { pulsed light } \\ \text { SDS } & \text { sodiumdodecyl sulfate } \\ \text { TAB } & \text { total aerobic bacteria } \\ \text { TPC } & \text { total plate count } \\ \text { TS } & \text { thermosonication } \\ \text { TV } & \text { tulane virus } \\ \text { US } & \text { ultrasound } \\ \text { UV } & \text { ultraviolet light } \\ \text { WPL } & \text { water-assisted pulsed light } \\ \text { WUV } & \text { water-assisted UV } \\ \text { YMC } & \text { yeasts and moulds count. } \\ & \end{array}$




\section{Appendix A}

Table A1. Main advantages and limitations of strategies for the control of microorganisms on fresh blueberries and products derived thereof.

\begin{tabular}{|c|c|c|c|}
\hline Strategies & Advantages & Limitations & Reference \\
\hline Chlorine dioxide $\left(\mathrm{ClO}_{2}\right)$ & $\begin{array}{l}\text { Gaseous chlorine dioxide }\left(\mathrm{gClO}_{2}\right) \\
-\quad \text { High penetration ability } \\
-\quad \text { Products do not require a subsequent washing } \\
-\quad \text { Greater efficacy than chlorine } \\
-\quad \text { Wide range of antimicrobial action } \\
\text { Aqueous } \mathrm{ClO}_{2} \\
\text { - } \quad \text { Higher antimicrobial efficacy at neutral pH } \\
\text { than chlorine } \\
\text { - Fewer carcinogenic halogenated disinfection } \\
\text { by-products (DBP) than chlorine }\end{array}$ & $\begin{array}{l}\text { Gaseous } \mathrm{gClO}_{2} \\
\text { - } \quad \text { Possible bleaching of fruits } \\
\text { - } \quad \text { Antimicrobial activity affected by gas concentration, } \\
\text { time of exposure, humidity and temperature } \\
\text { Aqueous } \mathrm{ClO}_{2} \\
\text { - } \quad \text { Low efficiency at permitted concentrations } \\
\text { - } \quad \text { Products require washing after treatment }\end{array}$ & {$[31,33,35]$} \\
\hline Ozone $\left(\mathrm{O}_{3}\right)$ & $\begin{array}{ll}\text { - } & \text { Generally recognized as safe (GRAS) } \\
\text { - } & \text { Decomposes to nontoxic products } \\
\text { - } & \text { High microbial action against bacterial pathogens }\end{array}$ & $\begin{array}{ll}\text { - } & \text { Risk of explosion and toxicity } \\
\text { - } & \text { At high concentrations it can cause undesirable } \\
\text { organoleptic changes } \\
\text { - } \quad \text { Requires on-site generation } \\
\text { - } \quad \begin{array}{l}\text { High concentrations and exposure times are required } \\
\text { to achieve significant microbial reductions }\end{array} \\
\text { - } \quad \text { Less effective against moulds and yeasts }\end{array}$ & {$[33,45,49]$} \\
\hline Peracetic acid (PAA) & $\begin{array}{ll}\text { - } & \text { Environmentally friendly } \\
\text { - } & \text { Tolerant to } \mathrm{pH} \text {, temperature, and organic load } \\
\text { - } & \text { Effective against bacterial pathogens }\end{array}$ & $\begin{array}{l}\text { Requires higher concentrations than those allowed } \\
\text { (80 ppm) to achieve significant microbial reduction }\end{array}$ & {$[33,53]$} \\
\hline Hydrogen peroxide $\left(\mathrm{H}_{2} \mathrm{O}_{2}\right)$ & $\begin{array}{ll}\text { - } & \text { Use in aqueous and gaseous form } \\
\text { - } & \text { No residue production }\end{array}$ & - $\quad$ High concentrations can affect product quality & {$[33,58]$} \\
\hline Organic acids & $\begin{array}{ll}\text { - } & \text { No toxicity } \\
\text { - } \quad \text { Economical and easy to use }\end{array}$ & $\begin{array}{l}\text { - Requires long exposure times to achieve significant } \\
\text { microbial reduction } \\
\text { - } \quad \text { Interferes with sensory quality }\end{array}$ & [33] \\
\hline
\end{tabular}


Table A1. Cont.

\begin{tabular}{|c|c|c|c|}
\hline Strategies & Advantages & Limitations & Reference \\
\hline Edible coatings & $\begin{array}{l}\text { - Antimicrobial action depending on the type of } \\
\text { material used } \\
\text { - } \quad \text { Can be used as carriers of different substances }\end{array}$ & $\begin{array}{ll}\text { - } & \text { High cost of materials } \\
\text { - } & \text { Loss of waxy bloom in the blueberries } \\
\text { - } & \text { Drawbacks in coating operations }\end{array}$ & {$[45,66]$} \\
\hline Ultraviolet (UV) & $\begin{array}{l}\text { - } \quad \text { Economical equipment and easy to use } \\
\text { - } \quad \text { compounds such as anthocyanins } \\
\text { - UV treatment can be combined with water } \\
\text { (water-assisted UV systems) in overhead and } \\
\text { submersible settings }\end{array}$ & $\begin{array}{ll}\text { - } & \text { Low penetration capacity } \\
\text { - } & \text { Sample heating } \\
\text { - } & \text { Shading effect }\end{array}$ & {$[33,83]$} \\
\hline Pulsed light (PL) & $\begin{array}{ll}\text { - } & \text { Significant microbial reductions in short } \\
\text { exposure times } \\
\text { - } \quad \text { Balanced cost } \\
\text { - } \quad \begin{array}{l}\text { PL can be combined with water } \\
\text { (water-assisted PL systems) }\end{array}\end{array}$ & $\begin{array}{l}\text { - } \quad \text { Low penetration in solid foods } \\
\text { - } \quad \text { High fluences can also lead to deterioration of } \\
\text { quality attributes }\end{array}$ & {$[35,94]$} \\
\hline $\begin{array}{l}\text { High hydrostatic pressure } \\
\qquad(\mathrm{HHP})\end{array}$ & $\begin{array}{ll}\text { - } & \text { Microbial and enzymatic inactivation } \\
\text { - } & \text { No degradation of flavour and nutrients }\end{array}$ & 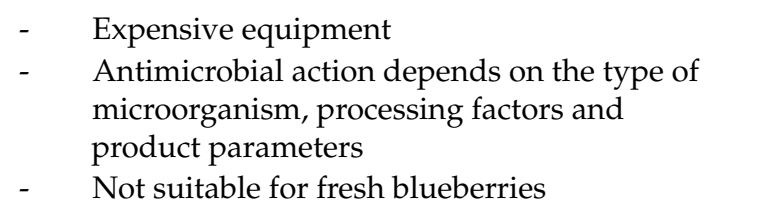 & [33] \\
\hline Pulsed electric field (PEF) & $\begin{array}{ll}\text { - } & \text { Treatment of liquid matrices } \\
\text { - } & \text { Minimal impact on product quality }\end{array}$ & $\begin{array}{ll}\text { - } & \text { Antimicrobial action influenced by product } \\
\text { - } & \text { parameters and type of microorganisms } \\
\text { - } & \text { Hot suitable for fresh blueberries } \\
\text { High cost }\end{array}$ & {$[109,110]$} \\
\hline Cold plasma $(\mathrm{CP})$ & $\begin{array}{l}\text { - } \quad \text { Can be used in liquid and solid products } \\
\text { - } \quad \text { Could be applied to the packed product }\end{array}$ & $\begin{array}{l}\text { - Possible changes in sensory properties and in the } \\
\text { content of bioactive compounds } \\
\text { - } \quad \text { Limited effect against moulds }\end{array}$ & {$[33,116]$} \\
\hline
\end{tabular}


Table A1. Cont.

\begin{tabular}{|c|c|c|c|}
\hline Strategies & Advantages & Limitations & Reference \\
\hline Ionizing irradiation & Can be used at room temperature and after packaging & 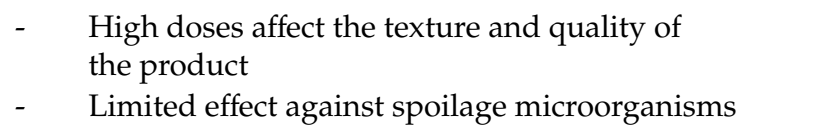 & {$[33,122]$} \\
\hline Ultrasound (US) & $\begin{array}{l}\text { - } \quad \text { Can be used in both liquid and solid matrices } \\
\text { - } \quad \text { Minimal impact on the quality of derived products }\end{array}$ & $\begin{array}{l}\text { - Needs to be combined with other strategies to be } \\
\text { more effective }\end{array}$ & {$[33,35]$} \\
\hline Biological compounds & $\begin{array}{ll}\text { - } & \text { Natural alternative } \\
\text { - } & \text { Added value to products }\end{array}$ & 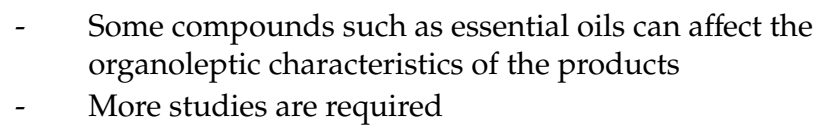 & {$[27,33]$} \\
\hline
\end{tabular}

Table A2. Chemical strategies for the control of microorganisms on fresh blueberries.

\begin{tabular}{|c|c|c|c|c|}
\hline Chemical Disinfectants & Microorganisms & Treatment Conditions & $\begin{array}{l}\text { Treatment Efficiency } \\
\text { (log Reduction) }\end{array}$ & Reference \\
\hline Gaseous chlorine dioxide $\left(\mathrm{gClO}_{2}\right)$ & TAB, YMC, E. coli, C. acutatum & $0.3-0.35 \mathrm{gClO}_{2}$ per pad & $\begin{array}{l}\text { TAB and } \mathrm{YMC} \text { : } \\
\text { Storage at } 20^{\circ} \mathrm{C} \text { : } \\
\geq 1.3 \log \mathrm{CFU} / \mathrm{g} \\
\text { Storage at } 10^{\circ} \mathrm{C} \text { for } 8 \mathrm{~d} \text { : } \\
\geq 1.7 \log \mathrm{CFU} / \mathrm{g} \\
\text { Storage at } 10^{\circ} \mathrm{C} \text { : } \\
\text { - } \quad \text { E. coli: } 2.2-3.3 \log \mathrm{CFU} / \mathrm{g} \\
\text { - C. acutatum: } 1.3-2.0 \log \mathrm{CFU} / \mathrm{g}\end{array}$ & [40] \\
\hline $\mathrm{gClO}_{2}$ & $\begin{array}{l}\text { Shiga toxin-producing E. coli } \\
\text { (STEC), Salmonella, and } L . \\
\text { monocytogenes }\end{array}$ & $\begin{array}{c}\text { Cumulative } \mathrm{gClO}_{2} \text { at } \\
1529 \mathrm{ppm}-\mathrm{h}\end{array}$ & $\begin{array}{l}\text { STEC, Salmonella and L. monocytogenes, } \\
\text { respectively: } \\
\text { - } \quad 3.9,3.9 \text {, and } 4.6 \log \text { CFU/g. }\end{array}$ & [37] \\
\hline
\end{tabular}


Table A2. Cont.

\begin{tabular}{|c|c|c|c|c|}
\hline Chemical Disinfectants & Microorganisms & Treatment Conditions & $\begin{array}{l}\text { Treatment Efficiency } \\
\text { (log Reduction) }\end{array}$ & Reference \\
\hline $\mathrm{gClO}_{2}$ & $\mathrm{TV}$ & $\begin{array}{c}\mathrm{gClO}_{2} \text { produced by acidified } \\
\mathrm{NaClO}_{2} \text { solutions ranging from } \\
0.1-10 \mathrm{mg} \text {. } \\
\text { Treatment times: } 5-330 \mathrm{~min}\end{array}$ & $\begin{array}{l}\left.\mathrm{gClO}_{2}(0.1 \mathrm{mg} \mathrm{NaClO})_{2}\right) \\
\text { - } \quad 1 \text { log after exposure for 30-330 min } \\
\mathrm{gClO}_{2}(1 \mathrm{mg} \mathrm{NaClO}): \\
\text { - } \quad 2.2 \log \text { after } 15 \mathrm{~min}\end{array}$ & [39] \\
\hline $\mathrm{gClO}_{2}$ & TV & $0.63-4.40$ (ppm-h/g product) & $\begin{array}{l}0.63(\mathrm{ppm}-\mathrm{h} / \mathrm{g}): \\
\text { - } \quad 3.82 \log \mathrm{PFU} / \mathrm{g}\end{array}$ & {$[38]$} \\
\hline $\mathrm{gClO}_{2}$ & S. enterica serovars & $3.55-6(\mathrm{ppm} / \mathrm{h} / \mathrm{g}$ product $)$ & $\begin{array}{l}5.5(\mathrm{ppm} / \mathrm{h} / \mathrm{g}): \\
\text { - } \quad 5.63-\log \mathrm{CFU} / \mathrm{g}\end{array}$ & {$[32]$} \\
\hline $\mathrm{gClO}_{2}$ and Ozone $\left(\mathrm{O}_{3}\right)$ & $\begin{array}{l}\text { STEC, S. enterica, } \\
\text { L. monocytogenes }\end{array}$ & $\begin{array}{c}\mathrm{gClO}_{2}: 0.04,0.07,0.15 \mathrm{mg} \\
\mathrm{ClO}_{2} / \mathrm{g} \text { produce for a } \\
5.0 \text { h exposure. }\end{array}$ & $\begin{array}{l}\mathrm{gClO}_{2} \text { was the best treatment: } \\
\text { - } \quad 3.7,2.7 \text {, and } 2.1 \text { log CFU/g in STEC, } \\
\text { Salmonella and L. monocytogenes, } \\
\text { respectively }(0.15 \mathrm{mg} \text { for } 5 \mathrm{~h}) .\end{array}$ & [51] \\
\hline $\begin{array}{l}\text { Sodium hypochlorite }(\mathrm{NaClO}) \\
\mathrm{ClO}_{2} \text { and Peracetic acid (PAA) }\end{array}$ & MNV-3 & $\begin{array}{c}\mathrm{NaClO}: 50 \mathrm{ppm} \\
\mathrm{ClO}_{2} 20 \mathrm{ppm} \\
\mathrm{PAA}: 85 \mathrm{ppm} \\
\text { Treatment time: } 1 \mathrm{~min}\end{array}$ & $\begin{array}{l}\text { With organic matter simulation: } \\
\text { - } \quad \mathrm{NaClO}:>4 \log \mathrm{PFU} / \mathrm{mL} \\
\text { - } \quad \text { PAA: } \sim 3 \log \mathrm{PFU} / \mathrm{mL}\end{array}$ & [42] \\
\hline $\mathrm{ClO}_{2}$ & $\mathrm{TAB}$ and $\mathrm{YMC}$ & $100 \mathrm{ppm}$ for $10 \mathrm{~min}$ & $\begin{array}{l}\text { - } \quad \text { TAB: } 1.4-1.5 \log \text { CFU/g. } \\
\text { - } \quad \text { YMC: } 0.8-0.9 \log \text { CFU/g. }\end{array}$ & [41] \\
\hline Chlorine and $\mathrm{O}_{3}$ & TPC and YMC & $\begin{array}{l}\text { Chlorine spray: } 100 \mathrm{mg} / \mathrm{L} . \\
\text { Aqueous ozone sprays: } 1 \mathrm{mg} / \mathrm{L} \text {. } \\
\text { Treatment time: } 60 \mathrm{s.}\end{array}$ & $\begin{array}{l}\text { Chlorine was the most effective treatment } \\
\text { after } 12 \text { months at }-18^{\circ} \mathrm{C} \text {. } \\
\text { - } \quad \text { TAB: below the detection limit } \\
\text { ( } 20 \text { CFU/g). } \\
\text { - YMC: } 1.5 \log \text { CFU/g (yeasts) and } \\
2 \text { log CFU/g (moulds). }\end{array}$ & [138] \\
\hline
\end{tabular}


Table A2. Cont.

\begin{tabular}{|c|c|c|c|c|}
\hline Chemical Disinfectants & Microorganisms & Treatment Conditions & $\begin{array}{l}\text { Treatment Efficiency } \\
\text { (log Reduction) }\end{array}$ & Reference \\
\hline & & & $\begin{array}{l}\text { On calyx and skin of blueberries, } \\
\text { respectively: }\end{array}$ & \\
\hline $\begin{array}{l}\text { Electrolyzed oxidizing water } \\
\text { (EOW), Ultraviolet light (UV), } \\
\mathrm{O}_{3} \text { and } \mathrm{O}_{3}+\mathrm{UV}\end{array}$ & E. coli O157:H7 & $\begin{array}{c}\text { EOW: } 46.1 \mathrm{mg} / \mathrm{L} \text { of residual } \\
\text { chlorine for } 4-26 \mathrm{~s} . \\
\text { UV: } 20 \mathrm{~mW} / \mathrm{cm}^{2} \text { for } 1-10 \mathrm{~min} . \\
\mathrm{O}_{3}: 4000 \mathrm{mg} / \mathrm{L} \text { for } 1 \mathrm{~min} \\
\mathrm{O}_{3}+\mathrm{UV}: 7.95 \mathrm{~mW} / \mathrm{cm}^{2} \text { for } \\
2 \mathrm{~min}+4000 \mathrm{mg} / \mathrm{L} \text { for } 1 \mathrm{~min} .\end{array}$ & $\begin{array}{l}\text { - } \quad \text { EOW: } 0.13-0.24 \text { and } \\
\text { 0.88-1.10 log CFU/g. } \\
\text { - } \mathrm{O}_{3}: 1.02 \text { and } 1.64 \log \mathrm{CFU} / \mathrm{g} \\
\text { - } \mathrm{UV} / 10 \mathrm{~min}: 2.14 \log \text { and } \\
4.05 \log \mathrm{CFU} / \mathrm{g} . \\
\text { - } \mathrm{O}_{3}+\mathrm{UV}:>1-2 \log \mathrm{CFU} / \mathrm{g} \text { in calyx of } \\
\text { blueberries than single combinations. }\end{array}$ & [52] \\
\hline $\begin{array}{c}\text { EOW, Bleach solution, ozonated } \\
\text { water and FIT }{ }^{\circledR} \text { solution }\end{array}$ & E. coli O157:H7 & $\begin{array}{l}\text { EOW: } 30 \mathrm{mg} / \mathrm{L} \text { free chlorine. } \\
\text { Bleach solution: } 100 \mathrm{mg} / \mathrm{L} \\
\text { free chlorine. } \\
\text { Ozonated water: } 1.5 \mathrm{mg} / \mathrm{L} \mathrm{O}_{3} \text {. } \\
\text { FIT }^{\circledR} \text { solution (levulinic acid). } \\
\text { Treatment time: } 1-5 \mathrm{~min}\end{array}$ & $\begin{array}{ll}\text { - } & \text { Bleach solution: } 4.4-4.8 \log \mathrm{CFU} / \mathrm{g} . \\
\text { - } & \text { EOW: } 3.9-4.4 \log \mathrm{CFU} / \mathrm{g} . \\
\text { - } & \text { Ozonoted solution: } 3.3-4.6 \log \mathrm{CFU} / \mathrm{g} . \\
& \end{array}$ & [49] \\
\hline $\begin{array}{l}\text { Controlled atmosphere storage } \\
\qquad \text { or } \mathrm{O}_{3}\end{array}$ & L. monocytogenes & $\begin{array}{l}\text { Controlled atmosphere storage: } \\
5 \% \mathrm{O}_{2}, 15 \% \mathrm{CO}_{2}, 80 \% \mathrm{~N}_{2} \text {. } \\
\text { Ozone gas: } 4 \text { ppm at } 4{ }^{\circ} \mathrm{C} \text { or } \\
2.5 \text { ppm at } 12{ }^{\circ} \mathrm{C} \text {. } \\
\text { Treatment time: } 10 \text { days } \\
\text { at } 4{ }^{\circ} \mathrm{C} \text { or } 12{ }^{\circ} \mathrm{C}\end{array}$ & $\begin{array}{l}\text { Ozone gas was the most effective treatment: } \\
\text { - } \quad 3 \text { and } 2 \log \mathrm{CFU} / \mathrm{mL} \text { at } 4 \text { and } \\
12^{\circ} \mathrm{C} \text {, respectively. }\end{array}$ & [50] \\
\hline $\begin{array}{l}\text { PAA, acidic EOW, near neutral } \\
\text { EOW, bleach and lactic acid. }\end{array}$ & $\begin{array}{l}\text { Strains of E. coli O157:H7, } \\
\text { S. Typhimurium DT104, } \\
\text { and L. monocytogenes. }\end{array}$ & $\begin{array}{c}\text { PAA: } 45-100 \mathrm{mg} / \mathrm{L} . \\
\text { Acidic EOW, near neutral EOW, } \\
\text { and bleach: } 100 \mathrm{mg} / \mathrm{L} \\
\text { free chlorine. } \\
\text { Lactic acid: } 2 \% . \\
\text { Treatment time: } 5 \mathrm{~min}\end{array}$ & $\begin{array}{l}\text { PAA at } 100 \mathrm{mg} / \mathrm{L} \text { was the best treatment. } \\
\text { - } \quad \text { E. coli O157:H7 } 6.7 \text { log CFU/g. } \\
\text { - } \quad \text { S. Typhimurium DT104 } 5.9 \text { log CFU/g. }\end{array}$ & [55] \\
\hline
\end{tabular}


Table A2. Cont.

\begin{tabular}{|c|c|c|c|c|}
\hline Chemical Disinfectants & Microorganisms & Treatment Conditions & $\begin{array}{l}\text { Treatment Efficiency } \\
\text { (log Reduction) }\end{array}$ & Reference \\
\hline Chlorine and PAA & $\begin{array}{l}\text { L. monocytogenes strains, } \\
\text { TPC and YMC }\end{array}$ & $\begin{array}{c}\text { Chlorine: } 100 \mathrm{ppm} . \\
0.4 \% \text { Neo-Pure (PAA } 450 \mathrm{ppm}) \text {. } \\
\text { Treatments with sanitizers for } \\
2 \text { min combined with storage at } \\
4{ }^{\circ} \mathrm{C}(14 \mathrm{~d}) \text { and at } \times 15{ }^{\circ} \mathrm{C}(28 \mathrm{~d}) .\end{array}$ & 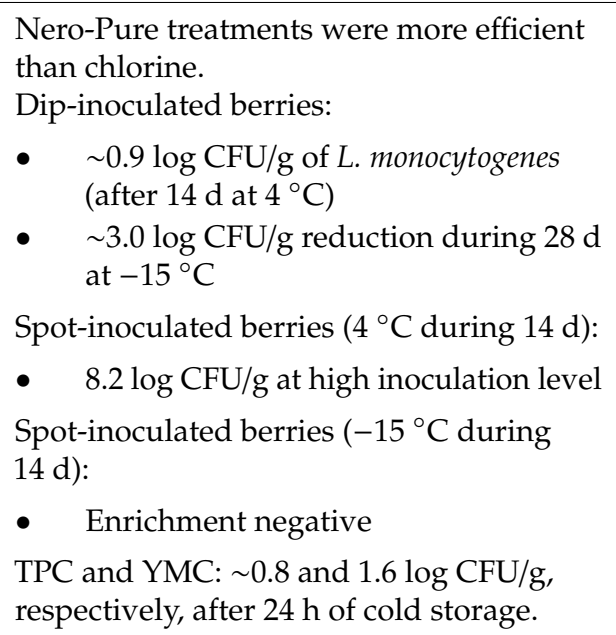 & [56] \\
\hline $\begin{array}{l}\text { Sodiumdodecyl sulfate (SDS) in } \\
\text { combination with } \\
\text { antimicrobial agents. }\end{array}$ & $\begin{array}{c}\text { S. enterica serovar Typhimurium } \\
\text { and YMC }\end{array}$ & $\begin{array}{l}\text { Chlorine: } 4-200 \mathrm{ppm} \text {. } \\
\text { Lactic acid, acetic acid, and citric } \\
\text { acid: } 0.05 \mathrm{mg} / \mathrm{mL} \text { or } 0.5 \mathrm{mg} / \mathrm{mL} \text {. } \\
\mathrm{H}_{2} \mathrm{O}_{2}: 50-200 \mathrm{ppm} \text {. } \\
\text { All treatments combined or not } \\
\text { with SDS: } 50-500 \mathrm{ppm} \text {. } \\
\text { Treatment time: } 1 \text { or } 5 \mathrm{~min} .\end{array}$ & $\begin{array}{l}0.5 \mathrm{mg} / \mathrm{mL} \text { acetic acid }+5000 \mathrm{ppm} \text { SDS } \\
(5 \mathrm{~min}): \\
\text { - } \quad \text { Salmonella: } 4.0 \log \mathrm{CFU} / \mathrm{g} . \\
\text { - } \quad \text { YMC: } 2.4 \log \mathrm{CFU} / \mathrm{g} \\
200 \mathrm{ppm} \text { hydrogen peroxide + } 5000 \mathrm{ppm} \\
\text { SDS ( } 5 \mathrm{~min}): \\
\text { - } \quad \text { Salmonella: } 4.2 \log \mathrm{CFU} / \mathrm{g} . \\
\text { - } \quad \text { YMC: } 2.0 \log \mathrm{CFU} / \mathrm{g} .\end{array}$ & [61] \\
\hline
\end{tabular}


Table A2. Cont.

\begin{tabular}{|c|c|c|c|c|}
\hline Chemical Disinfectants & Microorganisms & Treatment Conditions & $\begin{array}{l}\text { Treatment Efficiency } \\
\text { (log Reduction) }\end{array}$ & Reference \\
\hline $\begin{array}{l}\text { Electro-activated solutions of weak } \\
\text { organic acid salts }\end{array}$ & $\begin{array}{l}\text { L. monocytogenes. E. coli } \\
\text { O157:H7, Alternaria alternata, } \\
\text { Fusarium oxysporum, } \\
\text { and B. cinerea. }\end{array}$ & $\begin{array}{l}\text { Electro-activated solutions of } \\
3 \%(w / v) \text { : potassium acetate, } \\
\text { potassium citrate, } \\
\text { and calcium L-lactate. } \\
\text { Treatment time: } 0.5-5 \mathrm{~min} .\end{array}$ & $\begin{array}{l}\text { The reduction was dependent on the } \\
\text { treatment time. } \\
\text { All solutions ( } 5 \mathrm{~min}) \text { : } \\
\text { - } \quad \text { L. monocytogenes: } \sim 4 \log \mathrm{CFU} / \mathrm{g} \text {. } \\
\text { Potassium acetate and potassium citrate } \\
\text { solutions ( } 5 \mathrm{~min} \text { ): } \\
\text { - E. coli O157:H7: } \sim 3.5 \log \mathrm{CFU} / \mathrm{g} \text {. } \\
\text { Potassium acetate solution }(5 \mathrm{~min}) \text { : } \\
\text { - A. alternata: }>3 \text { log CFU } / \mathrm{g} \\
\text { - F. oxysporum and B. cinerea: } \\
\quad>5 \text { log CFU/g }\end{array}$ & [62] \\
\hline $\begin{array}{l}\text { Limonene and liposomal } \\
\text { nanoparticles with limonene. }\end{array}$ & YMC & $\begin{array}{c}50 \mu \mathrm{M} \text { limonene and liposomal } \\
\text { nanoparticles with } \\
50 \mu \mathrm{M} \text { limonene }\end{array}$ & $\begin{array}{l}\text { Liposomes: }>60 \% \text { reduction of } \\
\text { deterioration at the end of } 9 \text { weeks at } 4{ }^{\circ} \mathrm{C} \text {. }\end{array}$ & [79] \\
\hline Hot water & TPC and YMC & $\begin{array}{l}\text { Hot water: } 60-90{ }^{\circ} \mathrm{C} \text { with } \\
\text { (0.05 and } 0.1 \%) \text { or without } \\
\text { Boxyl }{ }^{\circledR} \text { (atomic oxygen). } \\
\text { Treatment time: } 10-30 \mathrm{~s} .\end{array}$ & $\begin{array}{l}\text { TAB reduction increased with temperature. } \\
\text { YMC reduction increased with temperature } \\
\text { and contact time. } \\
65 \text { to } 70{ }^{\circ} \mathrm{C}(10 \text { to } 15 \mathrm{~s}) \text { : } \\
\text { - } \quad \text { TAB: } 1.5 \log \mathrm{CFU} / \mathrm{g} \text {. } \\
\text { - } \quad \text { YMC: } 2.0 \log \mathrm{CFU} / \mathrm{g} \text {. }\end{array}$ & [139] \\
\hline Edible coatings & $\mathrm{TAB}$ and $\mathrm{YMC}$ & $\begin{array}{c}\text { Coating with } 1 \% \text { chitosan, } 1 \% \\
\text { acetic acid, } 0.75 \% \text { glycerol, } \\
0.25 \% \text { Tween- } 20 \text {, and } 0.1 \% \text { to } \\
0.5 \% \text { essential oils (carvacrol, } \\
\text { cinnamaldehyde, } \\
\text { and trans-cinnamaldehyde). }\end{array}$ & $\begin{array}{l}\text { Chitosan }+0.5 \% \text { trans-cinnamaldehyde: } \\
\text { TAB and YMC: } 2-3 \log \text { CFU/g } \\
\text { at } 7 \mathrm{~d} \text { at } 10^{\circ} \mathrm{C} \text {. }\end{array}$ & [72] \\
\hline
\end{tabular}


Table A2. Cont.

\begin{tabular}{|c|c|c|c|c|}
\hline Chemical Disinfectants & Microorganisms & Treatment Conditions & $\begin{array}{l}\text { Treatment Efficiency } \\
\text { (log Reduction) }\end{array}$ & Reference \\
\hline Edible coatings & YMC & $\begin{array}{c}\text { Quinoa protein }(0.62 \% w / v), \\
\text { sunflower oil }(3.8 \% w / v) \\
\text { and chitosan }(2 \% w / v) \text { in a ratio } \\
\text { of } 1: 1(v / v) .\end{array}$ & $\begin{array}{l}\text { Coating delayed YMC during } 32 \mathrm{~d} \text { at } 4{ }^{\circ} \mathrm{C} \\
\text { Control samples showed an increase of } \\
\text { YMC (1.8-3.1 log CFU/g) between } 20 \text { and } \\
35 \mathrm{~d} \text { of storage at } 4{ }^{\circ} \mathrm{C} \text {. }\end{array}$ & [73] \\
\hline Edible coatings & YMC & $\begin{array}{l}2 \% \text { chitosan coating. } \\
1.5 \% \text { sodium alginate coating. } \\
1.5 \% \text { chitosan and } 1 \% \text { sodium } \\
\text { alginate coating }\end{array}$ & $\begin{array}{l}\text { After } 45 \mathrm{~d} \text { at } 0{ }^{\circ} \mathrm{C} \text { : } \\
\text { Chitosan coating (both cultivars): } \\
\text { - } \quad \text { Yeasts: } 2.67-3.92 \log \mathrm{CFU} / \mathrm{g} \\
\text { Chitosan coating (cv Berkeley): } \\
\text { - } \quad \text { Moulds: } 1.35 \log \mathrm{CFU} / \mathrm{g} \\
\left.\text { Alginate coating (cv } \mathrm{O}^{\prime} \mathrm{Neal}\right): \\
\text { - } \quad \text { Moulds: } 2.74 \log \mathrm{CFU} / \mathrm{g}\end{array}$ & [63] \\
\hline Edible coatings & $\begin{array}{l}\text { Botrytis cinerea artificially } \\
\text { inoculated and YMC }\end{array}$ & $\begin{array}{c}\text { Chitosan or chitosan } \\
\text { coating }+ \text { Aloe vera. } \\
0.5 \%(w / v) \text { chitosan, } 0.5 \%(v / v) \\
\text { glycerol, } 0.1 \%(w / v) \text { Tween } 80, \\
\text { and } 0.5 \%(v / v) \text { Aloe vera } \\
\text { liquid fraction. }\end{array}$ & $\begin{array}{l}\text { After } 25 \text { days at } 5{ }^{\circ} \mathrm{C} \text { : } \\
\text { YMC in non-inoculated blueberries: } \\
\text { - Chitosan coating: }>1 \text { log CFU/g } \\
\text { - Chitosan coating + Aloe vera: } \\
\quad>2 \log \text { CFU/g } \\
\text { B. cinerea in inoculated blueberries: } \\
\text { - Chitosan coating + Aloe vera: } \\
\quad>1 \log \text { CFU/g }\end{array}$ & [74] \\
\hline Edible coatings & YMC & $\begin{array}{l}2 \% \text { chitosan coating. } \\
1.5 \% \text { sodium alginate coating. } \\
1.5 \% \text { chitosan and } 1 \% \text { sodium } \\
\text { alginate coating. }\end{array}$ & $\begin{array}{l}\text { After } 45 \text { days at } 0{ }^{\circ} \mathrm{C} \text { : } \\
\text { Chitosan edible coating was the } \\
\text { best treatment: } \\
\text { - } \quad \text { Yeasts: }>2.5 \log \mathrm{CFU} / \mathrm{g} \\
\text { - } \quad \text { Moulds: }>1 \log \mathrm{CFU} / \mathrm{g}\end{array}$ & [70] \\
\hline
\end{tabular}


Table A3. Physical technologies used alone or in combination with antimicrobial agents for the control of microorganisms on blueberries and products derived thereof.

\begin{tabular}{|c|c|c|c|c|c|}
\hline Technology & Microorganisms & Food Matrix & Treatment Conditions & $\begin{array}{l}\text { Treatment Efficiency } \\
\text { (log Reduction) }\end{array}$ & Reference \\
\hline Water-assisted UV (WUV) & MNV-1 & Fresh blueberries & $\begin{array}{c}\text { UV dose: } 12.000 \mathrm{~J} / \mathrm{m}^{2} \\
\text { Treatment time: } 1-5 \mathrm{~min} \text {. } \\
\text { Treatments under different conditions of } \\
\text { organic load. }\end{array}$ & $\begin{array}{l}\text { Small scale clear water/2 min: } \\
\text { - WUV: }>4.32 \text { log PFU/sample } \\
\text { - UV: } 2.48 \text { log PFU/sample } \\
\text { Large-scale water with COD } 2150 \mathrm{mg} / \mathrm{L} \\
\text { ( } 2 \text { min): } \\
\text { - } \quad \text { WUV + } 10 \mathrm{ppm} \text { chlorine: } \\
\quad 2.88 \text { log PFU/skin sample } \\
\text { - WUV + } 10 \text { ppm chlorine: } \\
\quad<2 \text { log PFU/calyx sample }\end{array}$ & [83] \\
\hline WUV & $\begin{array}{l}\text { Strains of E. coli O157:H7 } \\
\text { and Salmonella enterica }\end{array}$ & Fresh blueberries & $\begin{array}{c}\text { UV: } 7.9 \mathrm{~mW} / \mathrm{cm}^{2} \\
\text { WUV: } 4.6 \mathrm{~mW} / \mathrm{cm}^{2} \\
\text { Treatment time: } 2-10 \mathrm{~min} . \\
100 \mathrm{ppm} \text { of SDS, chlorinated water } \\
\text { (10 ppm free chlorine), or } 0.5 \% \text { levulinic } \\
\text { acid for } 10 \mathrm{~min} \text { with or without WUV } \\
\left(7.9 \mathrm{~W} / \mathrm{cm}^{2}\right) .\end{array}$ & $\begin{array}{l}\text { WUV treatment }>\text { efficiency than } \mathrm{UV} \\
\text { (average }>1.4 \log \mathrm{CFU} / \mathrm{g} \text { for } \\
\text { spot-inoculated blueberries). } \\
\text { UV treatments }<\text { efficiency ( }<2 \log \mathrm{CFU} / \mathrm{g} \\
\text { for dip inoculated blueberries). } \\
\text { Non-significant effect of added chemicals } \\
\text { in dip-inoculated on blueberries. }\end{array}$ & [87] \\
\hline WUV & Salmonella enterica strains & Fresh blueberry & $\begin{array}{l}\text { UV in turbid tap water with or without } \\
10 \text { ppm free chlorine, } 80 \mathrm{ppm} \text { PAA and } \\
1 \% \text { or } 2 \% \mathrm{H}_{2} \mathrm{O}_{2} \\
\text { UV intensity: } 23 \text { and } 28 \mathrm{~mW} / \mathrm{cm}^{2} \\
\text { Treatment time: } 2 \mathrm{~min}\end{array}$ & $\begin{array}{l}\text { WUV-Chlorine and WUV-PAA were the } \\
\text { best treatments. } \\
\text { Large-scale study WUV-PAA } \\
\text { and WUV-chlorine: } \\
\text { - } \quad 2.22 \log \text { CFU/g }\end{array}$ & [88] \\
\hline WUV & Salmonella enterica strains & Blueberries & $\begin{array}{c}\text { Submersible intensity: } 4 \mathrm{~mW} / \mathrm{cm}^{2} \\
\text { Treatment time: } 2 \mathrm{~min}\end{array}$ & $1.8-2.0 \log \mathrm{CFU} / \mathrm{g}$ & [85] \\
\hline WUV & Salmonella enterica strains & Blueberries & $\begin{array}{l}\text { Larger-scale study: } \\
\text { Intensity WUV: } 2-29 \mathrm{~mW} / \mathrm{cm}^{2} \\
\text { Treatment time: } 1 \text { or } 10 \mathrm{~min}\end{array}$ & $\begin{array}{l}\text { 10-min WUV }\left(29 \mathrm{~mW} / \mathrm{cm}^{2}\right) \\
\text { Spot and Dip inoculated products: } \\
\text { - } \quad 4.54-1.94 \log \mathrm{CFU} / \mathrm{g} \text {. }\end{array}$ & [86] \\
\hline
\end{tabular}


Table A3. Cont.

\begin{tabular}{|c|c|c|c|c|c|}
\hline Technology & Microorganisms & Food Matrix & Treatment Conditions & $\begin{array}{l}\text { Treatment Efficiency } \\
\text { (log Reduction) }\end{array}$ & Reference \\
\hline UV & $\begin{array}{c}\text { E. coli O157:H7, serovars } \\
\text { of Salmonella enterica, } \\
\text { L. monocytogenes, } \\
\text { Enterococcus faecium, E. coli } \\
\text { P1, Listeria innocua, MS2 } \\
\text { bacteriophage HAV, } \\
\text { and MNV. }\end{array}$ & $\begin{array}{l}\text { Fresh and frozen } \\
\text { blueberries. }\end{array}$ & $\begin{array}{c}20 \mathrm{~s}\left(212 \pm 25 \mathrm{~mJ} / \mathrm{cm}^{2}\right) \\
60 \mathrm{~s}\left(650 \pm 71 \mathrm{~mJ} / \mathrm{cm}^{2}\right) \\
120 \mathrm{~s}\left(1331 \pm 103 \mathrm{~mJ} / \mathrm{cm}^{2}\right)\end{array}$ & $\begin{array}{l}\text { HAV and MNV: } \\
\text { - } \quad>2-3 \log / g \text { in blueberries } \\
\text { - MNV in fresh berries > inactivation } \\
\text { than in frozen berries, unlike HAV. } \\
\text { Salmonella, E. coli O157:H7 and } \\
\text { L. monocytogenes: } \\
\text { - } \quad<1 \mathrm{log} / \mathrm{g} \\
\text { Treatment time has not significantly } \\
\text { improved inactivation in most of } \\
\text { the matrices. }\end{array}$ & [84] \\
\hline UV- $\mathrm{TiO}_{2}$ photocatalysis & Escherichia coli K12 & Fresh blueberries & $\begin{array}{c}\text { UV- } \mathrm{TiO}_{2} \text { photocatalysis: } 4.5 \mathrm{~mW} / \mathrm{cm}^{2} . \\
\text { UV: } 6.0 \mathrm{~mW} / \mathrm{cm}^{2} . \\
\text { Treatment time: } 0-10 \mathrm{~min}\end{array}$ & $\begin{array}{l}\text { UV-TiO } 2 \text { photocatalysis > efficiency UV. } \\
\text { - } \quad 5.3 \log \mathrm{CFU} / \mathrm{g} \text { on the } \\
\text { skin-inoculated blueberry }(30 \mathrm{~s}) . \\
\text { - } 5.2 \log \mathrm{CFU} / \mathrm{g} \text { on the blueberry } \\
\text { calyx }(10 \mathrm{~min}) .\end{array}$ & [91] \\
\hline $\begin{array}{l}\text { 405-nm monochromatic } \\
\text { blue light }\end{array}$ & TV & Fresh blueberries & $\begin{array}{c}\text { Intensity: } \\
4.2 \mathrm{~mW} / \mathrm{cm}^{2} . \\
\text { Treatment time: } 5-30 \mathrm{~min}\end{array}$ & $\begin{array}{l}\text { Treatment times resulted in a reduction } \\
\text { of }<0.2 \log \text { PFU } / \mathrm{mL} \text {. } \\
\text { - } \quad 1.01 \log \mathrm{PFU} / \mathrm{mL} \text { after a } 405 \mathrm{~nm} \\
\text { light treatment + Rose Bengal. }\end{array}$ & [140] \\
\hline $\begin{array}{l}\text { Water-assisted pulsed } \\
\text { light (WPL) }\end{array}$ & $\begin{array}{l}\text { YMC, strains of E. coli } \\
\text { O157:H7 and } \\
\text { Salmonella enterica. }\end{array}$ & Fresh blueberries & $\begin{array}{l}\text { Intensity: } 5.0-56.1 \mathrm{~J} / \mathrm{cm}^{2} \\
\text { Treatment time: } 5-60 \mathrm{~s}\end{array}$ & $\begin{array}{l}\text { The inactivation was time-dependent } \\
\text { - E. coli O157:H7: } 3.0 \text { and } \\
>5.8 \log \text { CFU/g on blueberry calyx } \\
\text { and skin, respectively ( } 60 \mathrm{~s}) \text {. } \\
\text { - Salmonella: } 3.6 \text { and } \\
>5.9 \text { log CFU/g on blueberry calyx and } \\
\text { skin, respectively ( } 60 \text { s). } \\
\text { WPL achieved a limited reduction } \\
\text { of YMC. }\end{array}$ & [23] \\
\hline
\end{tabular}


Table A3. Cont.

\begin{tabular}{|c|c|c|c|c|c|}
\hline Technology & Microorganisms & Food Matrix & Treatment Conditions & $\begin{array}{l}\text { Treatment Efficiency } \\
\text { (log Reduction) }\end{array}$ & Reference \\
\hline WPL & $\begin{array}{c}\text { Strains of } \\
\text { Salmonella enterica. }\end{array}$ & Fresh blueberries & $\begin{array}{c}\text { PL combined or not with } 1 \% \mathrm{H}_{2} \mathrm{O}_{2} \text { and } \\
\text { under different organic } \\
\text { loading conditions. } \\
\text { High PL: } 0.225-0.298 \mathrm{~J} / \mathrm{cm}^{2} \text {-pulse. } \\
\text { Low PL: } 0.102-0.140 \mathrm{~J} / \mathrm{cm}^{2} \text {-pulse. } \\
\text { Treatment time: } 0.5-1 \mathrm{~min} .\end{array}$ & $\begin{array}{l}\text { No significant differences between the } \\
\text { low and high creep PL treatments. } \\
\text { WPL }+1 \% \mathrm{H}_{2} \mathrm{O}_{2}(1 \mathrm{~min})>\text { efficiency for } \\
\text { reducing Salmonella in clear water by } \\
>5.6 \text { log CFU/g. } \\
\text { The high organic load condition did not } \\
\text { affect the efficacy of the WPL- } \mathrm{H}_{2} \mathrm{O}_{2} \text { for } \\
1 \mathrm{~min} \text {. }\end{array}$ & [99] \\
\hline WPL & $\begin{array}{l}\text { Salmonella enterica } \\
\text { serotypes and YMC }\end{array}$ & Fresh blueberries & $\begin{array}{l}\text { PL dose: } 6 \mathrm{~J} / \mathrm{cm}^{2}(30 \mathrm{~s}) \text {. } \\
\text { WPL dose: } 9 \mathrm{~J} / \mathrm{cm}^{2}(45 \mathrm{~s})\end{array}$ & $\begin{array}{l}\text { WPL was the most effective treatment: } \\
\text { - Salmonella: }>4.4 \text { and } 0.8 \log \mathrm{CFU} / \mathrm{g} \\
\text { for spot and dip } \\
\text { inoculation, respectively. } \\
\text { - YMC: } 0.9 \log \text { CFU/g. }\end{array}$ & [98] \\
\hline Pulsed light (PL) & $\begin{array}{c}\text { MNV-1, Escherichia coli } \\
\text { O157:H7 and } \\
\text { Salmonella Newport }\end{array}$ & Fresh blueberries & $\begin{array}{l}\text { Intensity: } 5.9-22.5 \mathrm{~J} / \mathrm{cm}^{2} \\
\text { Treatment time: } 6-24 \mathrm{~s} .\end{array}$ & $\begin{array}{l}\text { Increasing PL fluence yielded } \\
\text { significantly higher reductions } \\
\text { for Salmonella. } \\
\text { - } \quad \text { MNV-1: } 3.1-3.8 \text { PFU/sample } \\
\text { - } \quad \text { E. coli O157:H7: } 5.7 \text { log CFU/sample } \\
\text { (24 s) } \\
\text { - Salmonella: } 4.2 \log \text { CFU/sample } \\
\text { (24 s) }\end{array}$ & [97] \\
\hline WPL and WUV & Strains of Salmonella & Blueberry & $\begin{array}{l}\text { WUV: } \sim 13 \text { or } 28 \mathrm{~mW} / \mathrm{cm}^{2} . \\
\text { WPL: } \sim 0.15 \text { or } 0.30 \mathrm{~J} / \mathrm{cm}^{2} \text { per pulse. } \\
\text { Treatment time: } 1 \text { or } 2 \mathrm{~min}\end{array}$ & $\begin{array}{l}\text { Spot-inoculated: } \\
\text { - } \quad 4.5-5.7 \log \mathrm{CFU} / \mathrm{g} \\
\text { Dip-inoculated: } \\
\text { - } \quad 1.8-2.3 \log \mathrm{CFU} / \mathrm{g}\end{array}$ & [100] \\
\hline $\begin{array}{l}\text { High hydrostatic } \\
\text { pressure (HHP) }\end{array}$ & HuNoV GI.1 & Fresh blueberries & $\begin{array}{c}\text { Intensity: } 400-600 \mathrm{MPa} \text { (wet-state } \\
\text { samples) and } 600 \mathrm{MPa} \\
\text { (dry-state samples). } \\
\text { Pressure treatments: } 1 \text { or } 21^{\circ} \mathrm{C} \text { for } 2 \mathrm{~min} .\end{array}$ & $\begin{array}{l}\text { Pressure inactivation was more effective } \\
\text { at lower temperature and when } \\
\text { blueberries were surrounded by water. } \\
\text { - } \quad 2.7 \log \left(500 \mathrm{MPa} \text { at } 1{ }^{\circ} \mathrm{C} \text {, wet state }\right) \\
\text { - } \quad 0.5 \log \left(500 \mathrm{MPa} \text { at } 21^{\circ} \mathrm{C} \text {, wet state }\right)\end{array}$ & [103] \\
\hline
\end{tabular}


Table A3. Cont.

\begin{tabular}{|c|c|c|c|c|c|}
\hline Technology & Microorganisms & Food Matrix & Treatment Conditions & $\begin{array}{l}\text { Treatment Efficiency } \\
\quad \text { (log Reduction) }\end{array}$ & Reference \\
\hline HHP & TV and MNV-1 & Fresh blueberries & $\begin{array}{l}\text { Intensity: } 250-600 \mathrm{MPa}\left(4,21 \text { or } 35^{\circ} \mathrm{C}\right) \text {. } \\
\text { Treatment time: } 2 \text { min. } \\
\text { Specific pressure units according to virus } \\
\text { and sample. }\end{array}$ & $\begin{array}{l}\text { Dry state blueberries: } \\
\text { - } \quad 400 \text { and } 600 \mathrm{MPa} \text { ( } 3 \text { temperatures): } \\
\text { - } \quad \text { Pressure inactivation increased as } \\
\text { sample temperature decreased. } \\
\text { Wet state blueberries: } \\
\text { - } \quad 300 \mathrm{MPa} \text { at } 4{ }^{\circ} \mathrm{C}: \mathrm{TV} \text { below the } \\
\text { detection limit. } \\
\text { - } 400 \mathrm{MPa} \text { at } 4^{\circ} \mathrm{C}: \mathrm{MNV}-1 \text { below the } \\
\text { detection limit. }\end{array}$ & [104] \\
\hline $\begin{array}{l}\text { High-Pressure } \\
\text { Homogenization }\end{array}$ & $\begin{array}{c}\text { MNV-1, feline } \\
\text { calicivirus-F9 and } \\
\text { bacteriophage MS2 }\end{array}$ & Blueberry juice & $\begin{array}{l}\text { Intensity: 100-300 MPa. } \\
\text { Treatment time: }<2 \mathrm{~s}\end{array}$ & $\begin{array}{l}\text { - } \quad 4-5 \log \text { PFU/mL of FCV-F9 and MS2 } \\
\text { (100 MPa). } \\
0.71 \log \mathrm{PFU} / \mathrm{mL} \text { for MNV-1 } \\
\text { (300 MPa). }\end{array}$ & [141] \\
\hline HHP & HuNoV GI.1 and GII.4 & $\begin{array}{l}\text { Strawberries, blueberries, } \\
\text { raspberries, } \\
\text { and their purees }\end{array}$ & $\begin{array}{l}\text { Intensity: } 250 \text { to } 650 \mathrm{MPa}\left(0^{\circ} \mathrm{C}\right) \text {. } \\
\text { Treatment time: } 2 \mathrm{~min}\end{array}$ & $\begin{array}{l}\text { Highest reduction observed in } \\
\text { blueberries: } \\
\text { - } \quad>3.2 \text { log genomic copies/g with } \\
\text { - } \quad>450 \mathrm{MPa} \text { for GI.1 strain } \\
\quad 300 \mathrm{MPa} \text { for GII.4 strain } \\
\text { Purees: } \\
\text { - } \quad>2.9 \mathrm{log} \text { genomic copies/g with } \\
\quad \geq 550 \mathrm{MPa} \text { for HuNoV GI.1. } \\
\quad>4.0 \mathrm{log} \text { genomic copies/g with } \\
\quad \geq 550 \mathrm{MPa} \text { for HuNoV GII.4. }\end{array}$ & [102] \\
\hline
\end{tabular}


Table A3. Cont.

\begin{tabular}{|c|c|c|c|c|c|}
\hline Technology & Microorganisms & Food Matrix & Treatment Conditions & $\begin{array}{l}\text { Treatment Efficiency } \\
\text { (log Reduction) }\end{array}$ & Reference \\
\hline HHP & $\begin{array}{l}\text { O157 and Non-O157 } \\
\text { Serogroups of Shiga } \\
\text { Toxin-Producing E. coli }\end{array}$ & Blueberry juice & $\begin{array}{c}\text { Intensity: } 450 \mathrm{Mpa} \text { at } 4 \text { and } 45^{\circ} \mathrm{C} \text { with or } \\
\text { without antimicrobials and habituated } \\
\text { strains for } 3 \text {-days. } \\
\text { After habituation at } 4{ }^{\circ} \mathrm{C}: 0.5 \% \text { of } \\
\text { carvacrol and caprylic acid. } \\
\text { After habituation at } 45^{\circ} \mathrm{C}: 0.1 \% \text { of } \\
\text { carvacrol and caprylic acid. } \\
\text { Treatment time: } 1-7 \text { min }\end{array}$ & $\begin{array}{l}\text { Effects of habituation and antimicrobials } \\
\text { at } 45^{\circ} \mathrm{C} \text { were less pronounced than at } \\
4{ }^{\circ} \mathrm{C} \text {. } \\
450 \mathrm{MPa} \text { at } 4{ }^{\circ} \mathrm{C} \text { for } 7 \text { min } \\
\text { - Before habituation: } 1.4 \text { and } \\
1.6 \log \mathrm{CFU} / \mathrm{mL} \text { for O157 and } \\
\text { non-O157 serogroups. } \\
\text { - After habituation: } 2.6 \text { and } \\
3.3 \log \mathrm{CFU} / \mathrm{mL} \text { for O157 and } \\
\text { non-O157 serogroups. } \\
\text { - With carvacrol (after habituation): } \\
\text { 4.2 log CFU/mL for E. coli O157. } \\
\text { Without carvacrol (after } \\
\text { habituation): } 2.6 \log \mathrm{CFU} / \mathrm{mL} \text { for } \\
\text { E. coli O157. }\end{array}$ & [105] \\
\hline Pulsed electric field (PEF) & $\begin{array}{l}\text { E. coli } \mathrm{K} 12 \text { and } \\
\text { Listeria innocua inoculated } \\
\text { and natural microbiota }\end{array}$ & Fresh blueberries & $\begin{array}{l}\text { PEF: } 2 \mathrm{kV} / \mathrm{cm}, 1 \mu \text { s pulse width and } \\
100 \text { pulses per second, alone or in } \\
\text { combination with } 0.25-0.5 \% \text { PAA. } \\
\text { Treatment time: } 2-4 \text { min. }\end{array}$ & $\begin{array}{l}\text { Increased efficiency of PEF + PAA. } \\
\text { - E. coli and L. innocua: up to } \\
\text { - } \quad \text { log CFU/g } \\
\text { - Native microbiota: } 2 \log \text { CFU/g }\end{array}$ & [110] \\
\hline PEF & $\begin{array}{l}\text { S. cerevisiae, E. coli, } \\
\text { and S. aureus }\end{array}$ & Blueberry juice & $\begin{array}{c}\text { Voltage: } 100-500 \mathrm{~V} . \\
\text { Pulse duration: } 50-250 \mu \mathrm{s} . \\
\text { Pulse number: } 20-100 \text { pulses. }\end{array}$ & $\begin{array}{l}\text { Increased efficiency with voltage, pulse } \\
\text { duration and pulse number. } \\
500 \mathrm{~V} \text { for } 200 \mu \mathrm{s} \text { and } 80 \text { pulses: } \\
\text { - } \quad \text { S. cerevisiae: } 5.42 \log \mathrm{CFU} / \mathrm{mL} \\
\text { - } \quad \text { E. coli: } 5.32 \log \mathrm{CFU} / \mathrm{mL} \\
\text { - } \quad \text { S. aureus: } 4.77 \log \mathrm{CFU} / \mathrm{mL} \text {. }\end{array}$ & [109] \\
\hline Cold Plasma (CP) & TPC and YMC & Fresh blueberries & Atmospheric CP: 15-120 s & $\begin{array}{l}\text { - } \quad \mathrm{TPC}\left(4^{\circ} \mathrm{C} \text { for } 7 \mathrm{~d}\right): 1.5-2.0 \log \mathrm{CFU} / \mathrm{g} \\
\text { compared to the control. } \\
\text { CP did not significantly } \\
\text { reduce YMC. }\end{array}$ & [115] \\
\hline
\end{tabular}


Table A3. Cont.

\begin{tabular}{|c|c|c|c|c|c|}
\hline Technology & Microorganisms & Food Matrix & Treatment Conditions & $\begin{array}{l}\text { Treatment Efficiency } \\
\text { (log Reduction) }\end{array}$ & Reference \\
\hline $\mathrm{CP}$ & TV and MNV-1 & Fresh blueberries & $\begin{array}{l}\text { Cold plasma alone with } 4 \text { cubic } \\
\text { feet/minute }(\mathrm{cfm}) \text { or with } 7 \mathrm{cfm} \text { of } \\
\text { ambient-temperature air. } \\
\text { Treatment time: } 15-120 \mathrm{~s}\end{array}$ & $\begin{array}{l}\text { Virus inactivation was dependent on } \\
\text { treatment time. } \\
\text { Addition of } 7 \mathrm{cfm} \text { of ambient air: } \\
\text { - } \quad \mathrm{TV}: 3.5 \log \mathrm{PFU} / \mathrm{g}(120 \mathrm{~s}) \\
\text { - } \quad \mathrm{MNV}:>5 \log \mathrm{PFU} / \mathrm{g}(90 \mathrm{~s})\end{array}$ & [116] \\
\hline $\mathrm{CP}$ & TPC & Fresh blueberries & $\begin{array}{l}\text { Microwave power: } 9,7 \text {, and } 5 \mathrm{~W} \text {; argon } \\
\text { flow of } 7 \mathrm{~L} / \mathrm{min} \text {. Treatment time: } 15-60 \mathrm{~s}\end{array}$ & At 5 and $7 \mathrm{~W}(30 \mathrm{~s})$ : $>1 \mathrm{log}$. & [142] \\
\hline $\mathrm{CP}$ & Bacillus sp. & Blueberry juice & $\begin{array}{l}\mathrm{CP} \text { at } 11 \mathrm{kV} \text { and } 1000 \mathrm{~Hz} \\
\text { Oxygen: } 0,0.5 \% \text { and } 1 \% \\
\text { Treatment time: } 2-6 \mathrm{~min}\end{array}$ & $7.2 \log \left(6 \min y \mathrm{O}_{2} 1 \%\right)$ & [119] \\
\hline Ionizing radiation & $\begin{array}{l}\text { YMC, strains of } \\
\text { Salmonella enterica and } \\
\text { Listeria monocytogenes. }\end{array}$ & $\begin{array}{c}\text { Fresh blueberries } \\
\text { (Vaccinium corymbosum } \\
\text { cv. Bluecrop) }\end{array}$ & Gamma irradiation: $0.4 \mathrm{kGy}$ & $\begin{array}{l}\text { Irradiation did not significantly } \\
\text { affect YMC. } \\
\text { - Salmonella and L. monocytogenes } \\
\quad \text { reduced in } \sim 1 \log \text { CFU/g. }\end{array}$ & [123] \\
\hline Ionizing radiation & Toxoplasma gondii oocysts & Fresh blueberries & Gamma radiation: $0.2-0.6 \mathrm{kGy}$ at $4{ }^{\circ} \mathrm{C}$. & $\begin{array}{l}\text { All treatments produced reductions of } \\
4 \log \text { PFU/g beyond the detection limit of } \\
1 \log \text { PFU/g. }\end{array}$ & [124] \\
\hline Ionizing radiation & E. coli $\mathrm{K}-12$ & $\begin{array}{c}\text { Fresh blueberries } \\
\text { (Vaccinium corymbosum } \\
\text { cvs. Collins, Bluecrop) }\end{array}$ & Electron-beam: $0.5-3 \mathrm{kGy}$ & $\begin{array}{l}\text { E. coli } \mathrm{K}-12 \text { gradually decreased with the } \\
\text { increased dose. } \\
\text { With } 3.13 \mathrm{kGy} \text { : } \\
\text { - E. coli: } \sim 8 \log \mathrm{CFU} / \mathrm{g} \text { at } 3.13 \mathrm{kGy} \\
72 \% \text { decay at } 4{ }^{\circ} \mathrm{C} \text {, and } 70 \% \text { decay } \\
\text { at room temperature. }\end{array}$ & [125] \\
\hline Cavitation & $\begin{array}{c}\text { TPC, YMC, } \\
\text { and Heat-resistant mould }\end{array}$ & Blueberry Puree & $\begin{array}{l}\text { Heating: at } 40{ }^{\circ} \mathrm{C} \text { (stage } 1 \text { ), at } 80^{\circ} \mathrm{C} \\
\text { (stage 2), after } 10 \text { min holding at } 80^{\circ} \mathrm{C} \\
\text { (stage 3), and pasteurization from } 86 \text { to } \\
96^{\circ} \mathrm{C} \text { (stage } 4 \text { ) (continuous or steady } \\
\text { state with } 1 \text { to } 2 \text { min holding time). }\end{array}$ & $\begin{array}{l}\text { Heat-resistant moulds were inactivated } \\
\text { at } 94 \text { to } 96^{\circ} \mathrm{C} \text { within } 1 \text { to } 2 \text { min } \\
\text { holding time. } \\
\text { - } \quad \text { TPC in both slow and rapid } \\
\text { collected samples at temperatures } \\
\quad>86{ }^{\circ} \mathrm{C} \text { were } \leq 10 \mathrm{CFU} / \mathrm{g} \text {. } \\
\text { - YMC were undetectable for } \\
\text { all samples. } \\
\text { Blueberry purée products were } \\
\text { shelf-stable for } 24 \text { week-storage at } \\
\text { room temperature. }\end{array}$ & [143] \\
\hline
\end{tabular}


Table A3. Cont.

\begin{tabular}{|c|c|c|c|c|c|}
\hline Technology & Microorganisms & Food Matrix & Treatment Conditions & $\begin{array}{l}\text { Treatment Efficiency } \\
\text { (log Reduction) }\end{array}$ & Reference \\
\hline Ultrasound (US) & $\begin{array}{l}\text { Aspergillus ochraceus, } \\
\text { Penicillium expansum, } \\
\text { Rhodotorula sp., } \\
\text { Saccharomyces cerevisiae, } \\
\text { and Alicyclobacillus } \\
\text { acidoterrestris. }\end{array}$ & $\begin{array}{c}\text { Apple, cranberry, } \\
\text { and blueberry juice and } \\
\text { nectar }\end{array}$ & $\begin{array}{l}\text { Intensity: } 20 \mathrm{kHz} . \\
\text { Amplitude: } 60-120 \mu \mathrm{m} \text {. } \\
\text { Temperature: } 20-60^{\circ} \mathrm{C} \text {. } \\
\text { Treatment time: } 3-9 \mathrm{~min} \text {. }\end{array}$ & $\begin{array}{l}\text { US treatments at } 60^{\circ} \mathrm{C} \text { for } 3,6 \text { and } 9 \text { min: } \\
\text { - } \quad 3.56-5.93 \log \mathrm{CFU} / \mathrm{mL} \text { for all yeasts } \\
\text { and moulds } \\
\text { The treatments were not very effective } \\
\text { against } A \text {. acidoterrestris. }\end{array}$ & [129] \\
\hline US & TPC, YMC and coliforms & Blueberry juice & $\begin{array}{c}\text { Frequency: } 20 \mathrm{kHz} \\
\text { Flow: } 24 \mathrm{~mL} / \mathrm{min} \text { or } 93.5 \mathrm{~mL} / \mathrm{min} \text {. } \\
\text { Amplitude: } 40,80,100 \% \text {. }\end{array}$ & $\begin{array}{l}\text { US } 93.5 \mathrm{~mL} / \mathrm{min} / 100 \mathrm{~A}: \\
\text { - } \quad \text { TAB: } 1.36 \log \mathrm{CFU} / \mathrm{mL} \\
\text { - } \quad \text { YMC: } 1.18 \log \mathrm{CFU} / \mathrm{mL} \\
\text { - } \quad \text { Coliforms: } 1.28 \log \mathrm{CFU} / \mathrm{mL}\end{array}$ & [144] \\
\hline $\begin{array}{l}\text { Combination of US, heat, } \\
\text { and pressure. }\end{array}$ & Escherichia coli O157:H7 & Blueberry juice & $\begin{array}{c}\text { Heat: } \\
30-80^{\circ} \mathrm{C}(10 \mathrm{~min}) . \\
80^{\circ} \mathrm{C}(5-20 \mathrm{~min}) . \\
\text { Sonication: } \\
280-700 \mathrm{~W}, 20^{\circ} \mathrm{C} \text { for } 10 \mathrm{~min} \\
280-700 \mathrm{~W}, 30-60{ }^{\circ} \mathrm{C} \text { for } 10 \mathrm{~min} . \\
\text { TS: } 40^{\circ} \mathrm{C}, 560 \mathrm{~W} \text {. } \\
\text { MT: } 350 \mathrm{MPa}, 40^{\circ} \mathrm{C} \text {. } \\
\text { MS: } 560 \mathrm{~W}, 5 \mathrm{~min} / 350 \mathrm{MPa} . \\
\text { MTS: } 560 \mathrm{~W}, 5 \text { min, } 40^{\circ} \mathrm{C} / 350 \mathrm{MPa} \text {, } \\
40^{\circ} \mathrm{C} \text { for } 5-20 \mathrm{~min} .\end{array}$ & $\begin{array}{l}\text { Heat inactivation at } 80^{\circ} \mathrm{C}>\text { than the } \\
\text { other temperatures } \\
\text { - } \quad 80^{\circ} \mathrm{C}(10 \mathrm{~min}): 3.21 \log \mathrm{CFU} / \mathrm{mL} \text {. } \\
\text { - } \quad 80^{\circ} \mathrm{C}(20 \mathrm{~min}): 4.32 \log \mathrm{CFU} / \mathrm{mL} \text {. } \\
\text { The inactivation increased with } \\
\text { increasing sonication power: } \\
5.10 \log \mathrm{CFU} / \mathrm{mL}\left(60^{\circ} \mathrm{C}, 700 \mathrm{~W}\right) \text {. } \\
\text { - } \quad \mathrm{MTS} \text { and } \mathrm{MS}(5 \mathrm{~min}): 5.85 \text { and } \\
5.2 \log \mathrm{CFU} / \mathrm{mL} \text {, respectively. }\end{array}$ & [130] \\
\hline $\begin{array}{l}\text { US combined with } \\
\text { antimicrobial compounds }\end{array}$ & E. coli $\mathrm{K} 12$ and L. innocua & Fresh blueberries & $\begin{array}{c}\text { US: } 1 \mathrm{MHz} \text { or } 20 \mathrm{kHz} \text { alone or combined } \\
\text { with citral } 10 \mathrm{mM} \text {. } \\
\text { Treatment time: } 30 \text { or } 15 \mathrm{~min}\end{array}$ & $\begin{array}{l}\text { Citral + US } 1 \mathrm{MHz}(30 \mathrm{~min}): \\
\text { - } \quad \text { E. coli } \mathrm{K} 12: 5.23 \log \mathrm{CFU} / \mathrm{g} . \\
\text { Citral + US } 20 \mathrm{kHz}(15 \mathrm{~min}): \\
\text { - } \quad \text {. innocua: } \sim 3 \log \mathrm{CFU} / \mathrm{g} .\end{array}$ & [130] \\
\hline Cooling & $\begin{array}{c}\text { Serovars of } \\
\text { Salmonella enterica }\end{array}$ & $\begin{array}{l}\text { Southern highbush } \\
\text { blueberries (mixture of } \\
\text { "Farthing", "Sweetcrisp", } \\
\text { and "Emerald") }\end{array}$ & $\begin{array}{l}\text { Forced-air cooling: } 60-90 \mathrm{~min} \text {. } \\
\text { Hydrocooling with no sanitizer: } 6 \mathrm{~min} \text {. } \\
\text { Hydrocooling with } 150 \mathrm{ppm} \text { free } \\
\text { chlorine: } 6 \mathrm{~min}\end{array}$ & $\begin{array}{l}\text { Hydrocooling with sanitizer was the } \\
\text { most effective treatment: }>4 \log \mathrm{CFU} / \mathrm{g} \text { at } \\
\text { day } 0 \text {. } \\
\text { Hydrocooling with sanitizer }+21 \mathrm{~d} \\
\text { storage: }>5 \log \text { CFU/g. }\end{array}$ & [145] \\
\hline
\end{tabular}




\section{References}

1. Jimenez-Garcia, S.N.; Guevara-Gonzalez, R.G.; Miranda-Lopez, R.; Feregrino-Perez, A.A.; Torres-Pacheco, I.; Vazquez-Cruz, M.A. Functional properties and quality characteristics of bioactive compounds in berries: Biochemistry, biotechnology, and genomics. Food Res. Int. 2013, 54, 1195-1207. [CrossRef]

2. Nile, S.H.; Park, S.W. Edible berries: Bioactive components and their effect on human health. Nutrition 2014, 30, 134-144. [CrossRef] [PubMed]

3. Cassidy, A. Berry anthocyanin intake and cardiovascular health. Mol. Asp. Med. 2018, 61, 76-82. [CrossRef] [PubMed]

4. Istek, N.; Gurbuz, O. Investigation of the impact of blueberries on metabolic factors influencing health. J. Funct. Foods 2017, 38, 298-307. [CrossRef]

5. Neto, C.C. Cranberry and blueberry: Evidence for protective effects against cancer and vascular diseases. Mol. Nutr. Food Res. 2007, 51, 652-664. [CrossRef]

6. Norberto, S.; Silva, S.; Meireles, M.; Faria, A.; Pintado, M.; Calhau, C. Blueberry anthocyanins in health promotion: A metabolic overview. J. Funct. Foods 2013, 5, 1518-1528. [CrossRef]

7. Ryser, E.T.; Marth, E.H. Listeria, Listeriosis, and Food Safety; CRC Press: Boca Raton, FL, USA, 2007.

8. Calder, L.; Simmons, G.; Thornley, C. An outbreak of hepatitis A associated with consumption of raw blueberries. Epidemiol. Infect. 2003, 131, 745-751. [CrossRef]

9. Luna-Gierke, R.E.; Griffin, P.M.; Gould, L.H.; Herman, K.; Boop, C.A.; Strockbine, N.; Mody, R.K. Outbreaks of non-O157 Shiga toxin-producing Escherichia coli infection: USA. Epidemiol. Infect. 2014, 2270-2280. [CrossRef]

10. National Outbreak Reporting System (NORS). Dashboard CDC. Available online: https://wwwn.cdc.gov/ norsdashboard/ (accessed on 31 August 2020).

11. Miller, B.D.; Rigdon, C.E.; Robinson, T.J.; Hedberg, C.; Smith, K.E. Use of Global Trade Item Numbers in the Investigation of a Salmonella Newport Outbreak Associated with Blueberries in Minnesota, 2010. J. Food Prot. 2013, 76, 762-769. [CrossRef]

12. RASFF. Portal. Available online: https://webgate.ec.europa.eu/rasff-window/portal/?event=notificationDetail\& NOTIF_REFERENCE=2020.0759 (accessed on 31 August 2020).

13. RASFF. Portal. Available online: https://webgate.ec.europa.eu/rasff-window/portal/?event=notificationDetail\& NOTIF_REFERENCE=2018.3574 (accessed on 31 August 2020).

14. EFSA. Scientific Opinion on the risk posed by pathogens in food of non-animal origin. Part 2 (Salmonella and Norovirus in berries) 1. EFSA J. 2014, 12, 1-95. [CrossRef]

15. Gazula, H.; Quansah, J.; Allen, R.; Scherm, H.; Li, C.; Takeda, F.; Chen, J. Microbial loads on selected fresh blueberry packing lines. Food Control 2019, 100, 315-320. [CrossRef]

16. Quansah, J.K.; Gazula, H.; Holland, R.; Scherm, H.; Li, C.; Takeda, F.; Chen, J. Microbial quality of blueberries for the fresh market. Food Control 2019, 100, 92-96. [CrossRef]

17. Eckert, J.W.; Ogawa, J.M. The Chemical Control of Postharvest Diseases: Deciduous Fruits, Berries, Vegetables and Root/Tuber Crops. Annu. Rev. Phytopathol. 1988, 26, 433-469. [CrossRef]

18. Tournas, V.H.; Katsoudas, E. Mould and yeast flora in fresh berries, grapes and citrus fruits. Int. J. Food Microbiol. 2005, 105, 11-17. [CrossRef] [PubMed]

19. Wang, S.Y.; Chen, C.; Yin, J. Effect of allyl isothiocyanate on antioxidants and fruit decay of blueberries. Food Chem. 2010, 120, 199-204. [CrossRef]

20. Forney, C.F. Postharvest issues in blueberry and cranberry and methods to improve market-life. Acta Hortic. 2009, 810, 785-798. [CrossRef]

21. USHBC. Available online: Blueberries-retail-channel-w-Wild.vLogo_.pdf (accessed on 31 August 2020).

22. CBI-Centre for the Promotion of Imports from Developing Countries. The European Market Potential for Fresh Blueberries. Available online: https://www.cbi.eu/market-information/fresh-fruit-vegetables/blueberries/ market-potential (accessed on 31 August 2020).

23. Huang, Y.; Chen, H. A novel water-assisted pulsed light processing for decontamination of blueberries. Food Microbiol. 2014, 40, 1-8. [CrossRef]

24. Sy, K.V.; Watters, K.H.; Beuchat, L. Efficacy of Gaseous Chlorine Dioxide as a Sanitizer for Killing Salmonella, Yeasts, and Molds on Blueberries, Strawberries, and Raspberries. J. Food Prot. 2005, 68, 1165-1175. [CrossRef] 
25. Crowe, K.M.; Bushway, A.A.; Bushway, R.J.; Crowe, K.M.; Bushway, A.A. Effects of Alternative Postharvest Treatments on the Microbiological Quality of Lowbush Blueberries. Small Fruits Rev. 2005, 4, $29-39$. [CrossRef]

26. Lafarga, T.; Colás-medà, P.; Abadías, M.; Aguiló-aguayo, I.; Bobo, G. Strategies to reduce microbial risk and improve quality of fresh and processed strawberries: A review. Innov. Food Sci. Emerg. Technol. 2019, 52, 197-212. [CrossRef]

27. Meireles, A.; Giaouris, E.; Simões, M. Alternative disinfection methods to chlorine for use in the fresh-cut industry. FRIN 2016, 82, 71-85. [CrossRef]

28. Beuchat, L.R.; Pettigrew, C.A.; Tremblay, M.E.; Roselle, B.J.; Scouten, A.J. Lethality of Chlorine, Chlorine Dioxide, and a Commercial Fruit and Vegetable Sanitizer to Vegetative Cells and Spores of Bacillus cereus and Spores of Bacillus thuringiensis. J. Food Prot. 2004, 67, 1702-1708. [CrossRef] [PubMed]

29. Olmez, H.; Kretzschmar, U. Potential alternative disinfection methods for organic fresh-cut industry for minimizing water consumption and environmental impact. LWT Food Sci. Technol. 2009, 42, 686-693. [CrossRef]

30. Wu, V.C.H.; Kim, B. Effect of a simple chlorine dioxide method for controlling five foodborne pathogens, yeasts and molds on blueberries. Food Microbiol. 2007, 24, 794-800. [CrossRef] [PubMed]

31. Sun, X.; Baldwin, E.; Bai, J. Applications of gaseous chlorine dioxide on postharvest handling and storage of fruits and vegetables-A review. Food Control 2019, 95, 18-26. [CrossRef]

32. Annous, B.A.; Buckley, D.; Burke, A. Evaluation of Chlorine Dioxide Gas against Four Salmonella enterica Serovars Artificially Contaminated on Whole Blueberries. J. Food Prot. 2020, 83, 412-417. [CrossRef]

33. Ramos, B.; Miller, F.A.; Brandão, T.R.S.; Teixeira, P.; Silva, C.L.M. Fresh fruits and vegetables-An overview on applied methodologies to improve its quality and safety. Innov. Food Sci. Emerg. Technol. 2013, 20, 1-15. [CrossRef]

34. CFR-Code of Federal Regulations Title 21. Available online: https://www.accessdata.fda.gov/scripts/cdrh/ cfdocs/cfcfr/CFRSearch.cfm?fr=173.300 (accessed on 31 August 2020).

35. Deng, L.Z.; Mujumdar, A.S.; Pan, Z.; Vidyarthi, S.K.; Xu, J.; Zielinska, M.; Xiao, H.-W. Emerging chemical and physical disinfection technologies of fruits and vegetables: A comprehensive review. Crit. Rev. Food Sci. Nutr. 2020, 60, 2481-2508. [CrossRef]

36. Zhang, L.; Yan, Z.; Hanson, E.J.; Ryser, E.T. Efficacy of chlorine dioxide gas and freezing rate on the microbiological quality of frozen blueberries. Food Control 2015, 47, 114-119. [CrossRef]

37. Chai, H.-E.; Hwang, C.A.; Huang, L.; Wu, V.C.H.; Sheen, L.Y. Feasibility and efficacy of using gaseous chlorine dioxide generated by sodium chlorite-acid reaction for decontamination of foodborne pathogens on produce. Food Control 2020, 108, 106839. [CrossRef]

38. Kingsley, D.H.; Annous, B.A. Evaluation of Steady-State Gaseous Chlorine Dioxide Treatment for the Inactivation of Tulane virus on Berry Fruits. Food Environ. Virol. 2019, 11, 214-219. [CrossRef] [PubMed]

39. Kingsley, D.H.; Pérez-pérez, R.E.; Niemira, B.A.; Fan, X. Evaluation of gaseous chlorine dioxide for the inactivation of Tulane virus. Int. J. Food Microbiol. 2018, 273, 28-32. [CrossRef]

40. Sun, X.; Bai, J.; Ference, C.; Wang, Z.H.E.; Zhang, Y.; Narciso, J.A.N.; Zhou, K. Antimicrobial Activity of Controlled-Release Chlorine Dioxide Gas on Fresh Blueberries 1. J. Food Prot. 2014, 77, 1127-1132. [CrossRef]

41. Chun, H.H.; Kang, J.H.; Song, K.B. Effects of aqueous chlorine dioxide treatment and cold storage on microbial growth and quality of blueberries. J. Korean Soc. Appl. Biol. Chem. 2013, 56, 309-315. [CrossRef]

42. Girard, M.; Mattison, K.; Fliss, I.; Jean, J. Efficacy of oxidizing disinfectants at inactivating murine norovirus on ready-to-eat foods. Int. J. Food Microbiol. 2016, 219, 7-11. [CrossRef] [PubMed]

43. Xu, F.; Wang, S.; Xu, J.; Liu, S.; Li, G. Effects of combined aqueous chlorine dioxide and UV-C on shelf-life quality of blueberries. Postharvest Biol. Technol. 2016, 117, 125-131. [CrossRef]

44. Feliziani, E.; Lichter, A.; Smilanick, J.L.; Ippolito, A. Disinfecting agents for controlling fruit and vegetable diseases after harvest. Postharvest Biol. Technol. 2016, 122, 53-69. [CrossRef]

45. Huynh, N.K.; Wilson, M.D.; Eyles, A.; Stanley, R.A. Recent advances in postharvest technologies to extend the shelf life of blueberries (Vaccinium sp.), raspberries (Rubus idaeus L.) and blackberries (Rubus sp.). J. Berry Res. 2019, 9, 687-707. [CrossRef]

46. Bialka, K.L.; Demirci, A. Decontamination of Escherichia coli O157:H7 and Salmonella enterica on blueberries using ozone and pulsed UV-light. J. Food Sci. 2007, 72, 391-396. [CrossRef] 
47. Concha-Meyer, A.; Eifert, J.D.; Williams, R.C.; Marcy, J.E.; Welbaum, G.E. Shelf Life Determination of Fresh Blueberries (Vaccinium corymbosum) Stored under Controlled Atmosphere and Ozone. Available online: https://www.hindawi.com/journals/ijfs/2015/164143/ (accessed on 31 August 2020).

48. Jaramillo-Sánchez, G.; Contigiani, E.V.; Castro, M.A.; Hodara, K.; Alzamora, S.M.; Loredo, A.G.; Nieto, A.B. Freshness Maintenance of Blueberries (Vaccinium corymbosum L.) during Postharvest Using Ozone in Aqueous Phase: Microbiological, Structure, and Mechanical issues. Food Bioprocess. Technol. 2019, 12, 2136-2147. [CrossRef]

49. Pangloli, P.; Hung, Y. Reducing microbiological safety risk on blueberries through innovative washing technologies. Food Control 2013, 32, 621-625. [CrossRef]

50. Concha-meyer, A.; Eifert, J.; Williams, R.; Marcy, J.; Welbaum, G. Survival of Listeria monocytogenes on Fresh Blueberries (Vaccinium corymbosum) Stored under Controlled Atmosphere and Ozone. J. Food Prot. 2014, 77, 832-836. [CrossRef] [PubMed]

51. Bridges, D.F.; Rane, B.; Wu, V.C.H. The effectiveness of closed-circulation gaseous chlorine dioxide or ozone treatment against bacterial pathogens on produce. Food Control 2018, 91, 261-267. [CrossRef]

52. Kim, C.; Hung, Y. Inactivation of E. coli O157: H7 on Blueberries by Electrolyzed Water, Ultraviolet Light, and Ozone. J. Food Sci. 2012, 77, M206-M211. [CrossRef] [PubMed]

53. Artés, F.; Gómez, P.; Aguayo, E.; Escalona, V.; Artés-hernández, F. Sustainable sanitation techniques for keeping quality and safety of fresh-cut plant commodities. Postharvest Biol. Technol. 51 2009, 51, 287-296. [CrossRef]

54. Rood, L.; Koutoulis, A.; Bowman, J.P.; Evans, D.E.; Stanley, R.A.; Kaur, M. Control of microbes on barley grains using peroxyacetic acid and electrolysed water as antimicrobial agents. Food Microbiol. 2018, 76, 103-109. [CrossRef]

55. Singh, P.; Hung, Y.; Qi, H. Efficacy of Peracetic Acid in Inactivating Foodborne Pathogens on Fresh Produce Surface. J. Food Sci. 2018, 88, 432-439. [CrossRef]

56. Sheng, L.; Tsai, H.; Zhu, H.; Zhu, M. Survival of Listeria monocytogenes on blueberries post-sanitizer treatments and subsequent cold storages. Food Control 2019, 100, 138-143. [CrossRef]

57. Callahan, S.; Perry, J.J. Survival of Listeria innocua and Native Microflora in Sanitizer-Treated Wild Blueberries (Vaccinium angustifolium). Int. J. Fruit Sci. 2019, 1-16. [CrossRef]

58. de Siqueira Oliveira, L.; Eça, K.S.; de Aquino, A.C.; Vasconcelos, L.B. Chapter 4-Hydrogen Peroxide $\left(\mathrm{H}_{2} \mathrm{O}_{2}\right)$ for Postharvest Fruit and Vegetable Disinfection. In Postharvest Disinfection of Fruits and Vegetables; Siddiqui, M.W., Ed.; Academic Press: Cambridge, MA, USA, 2018; pp. 91-99, ISBN 978-0-12-812698-1.

59. Becker, B.; Dabisch-Ruthe, M.; Pfannebecker, J. Inactivation of Murine Norovirus on Fruit and Vegetable Surfaces by Vapor Phase Hydrogen Peroxide. J. Food Prot. 2020, 83, 45-51. [CrossRef]

60. Rico, D.; Martín-Diana, A.B.; Barat, J.M.; Barry-Ryan, C. Extending and measuring the quality of fresh-cut fruit and vegetables: A review. Trends Food Sci. Technol. 2007, 18, 373-386. [CrossRef]

61. Li, Y.; Wu, C. Enhanced inactivation of Salmonella Typhimurium from blueberries by combinations of sodium dodecyl sulfate with organic acids or hydrogen peroxide. FRIN 2013, 54, 1553-1559. [CrossRef]

62. Liato, V.; Hammami, R.; Aïder, M. In fluence of electro-activated solutions of weak organic acid salts on microbial quality and overall appearance of blueberries during storage. Food Microbiol. 2017, 64, 56-64. [CrossRef] [PubMed]

63. Chiabrando, V.; Giacalone, G. Anthocyanins, phenolics and antioxidant capacity after fresh storage of blueberry treated with edible coatings. Int. J. Food Sci. Nutr. 2015, 1-6. [CrossRef] [PubMed]

64. Duan, J.; Wu, R.; Strik, B.C.; Zhao, Y. Effect of edible coatings on the quality of fresh blueberries (Duke and Elliott) under commercial storage conditions. Postharvest Biol. Technol. 2011, 59, 71-79. [CrossRef]

65. Dhall, R.K. Advances in Edible Coatings for Fresh Fruits and Vegetables: A Review. Crit. Rev. Food Sci. Nutr. 2013, 53, 435-450. [CrossRef]

66. Lin, D.; Zhao, Y. Innovations in the Development and Application of Edible Coatings for Fresh and Minimally Processed Fruits and Vegetables. Compr. Rev. Food Sci. Food Saf. 2007, 6, 60-75. [CrossRef]

67. Rabea, E.I.; Stevens, C.V.; Smagghe, G.; Steurbaut, W. Chitosan as Antimicrobial Agent: Applications and Mode of Action. Biomacromolecules 2003, 4, 1457-1465. [CrossRef]

68. Hosseinnejad, M.; Jafari, S.M. Evaluation of different factors affecting antimicrobial properties of chitosan. Int. J. Biol. Macromol. 2016, 85, 467-475. [CrossRef] 
69. Abugoch, L.E.; Tapia, C.; Villamán, M.C.; Yazdani-Pedram, M.; Díaz-Dosque, M. Characterization of quinoa protein-chitosan blend edible films. Food Hydrocoll. 2011, 25, 879-886. [CrossRef]

70. Chiabrando, V.; Giacalone, G. Quality evaluation of blueberries coated with chitosan and sodium alginate during postharvest storage. Int. Food Res. J. 2017, 24, 1553-1561.

71. Jiang, H.; Sun, Z.; Jia, R.; Wang, X.; Huang, J. Efect of Chitosan as an Antifungal and Preservative Agent on Postharvest Blueberry. J. Food Qual. 2016, 39, 516-523. [CrossRef]

72. Sun, X.; Narciso, J.; Wang, Z.; Ference, C.; Bai, J.; Zhou, K. Effects of Chitosan-Essential Oil Coatings on Safety and Quality of Fresh Blueberries. J. Food Sci. 2014, 79, 955-960. [CrossRef]

73. Abugoch, L.; Tapia, C.; Plasencia, D.; Pastor, A.; Castro-Mandujano, O.; López, L.; Escalona, V.H. Shelf-life of fresh blueberries coated with quinoa protein/chitosan/sunflower oil edible film. J. Sci. Food Agric. 2015, 96, 619-626. [CrossRef]

74. Vieira, J.M.; Flores-lópez, M.L.; Jasso de Rodríguez, D.; Sousa, M.C.; Vicente, A.A.; Martins, J.T. Effect of chitosan-Aloe vera coating on postharvest quality of blueberry (Vaccinium corymbosum) fruit. Postharvest Biol. Technol. 2016, 116, 88-97. [CrossRef]

75. Alvarez, M.V.; Ponce, A.G.; Moreira, M.R. Influence of polysaccharide-based edible coatings as carriers of prebiotic fibers on quality attributes of ready-to-eat fresh blueberries. J. Sci. Food Agric. 2018, 98, 2587-2597. [CrossRef] [PubMed]

76. Yang, G.; Yue, J.; Gong, X.; Qian, B.; Wang, H.; Deng, Y.; Zhao, Y. Blueberry leaf extracts incorporated chitosan coatings for preserving postharvest quality of fresh blueberries. Postharvest Biol. Technol. 2014, 92, 46-53. [CrossRef]

77. Falcó, I.; Randazzo, W.; Sánchez, G.; López-Rubio, A.; Fabra, M.J. On the use of carrageenan matrices for the development of antiviral edible coatings of interest in berries. Food Hydrocoll. 2019, 92, 74-85. [CrossRef]

78. Moreno, M.A.; Bojorges, H.; Falcó, I.; Sánchez, G.; López-Carballo, G.; López-Rubio, A.; Zampini, I.C.; Isla, M.I.; Fabra, M.J. Active properties of edible marine polysaccharide-based coatings containing Larrea nitida polyphenols enriched extract. Food Hydrocoll. 2020, 102, 105595. [CrossRef]

79. Umagiliyage, A.L.; Becerra-Mora, N.; Kohli, P.; Fisher, D.J.; Choudhary, R. Antimicrobial efficacy of liposomes containing d-limonene and its effect on the storage life of blueberries. Postharvest Biol. Technol. 2017, 128, 130-137. [CrossRef]

80. Zhang, Z.H.; Wang, L.H.; Zeng, X.A.; Han, Z.; Brennan, C.S. Non-thermal technologies and its current and future application in the food industry: A review. Int. J. Food Sci. Technol. 2019, 54, 1-13. [CrossRef]

81. Keklik, N.M.; Krishnamurthy, K.; Demirci, A. 12-Microbial decontamination of food by ultraviolet (UV) and pulsed UV light. In Microbial Decontamination in the Food Industry; Demirci, A., Ngadi, M.O., Eds.; Woodhead Publishing: Cambridge, UK, 2012; pp. 344-369, ISBN 978-0-85709-085-0.

82. Lado, B.H.; Yousef, A.E. Alternative food-preservation technologies: Efficacy and mechanisms. Microbes Infect. 2002, 4, 433-440. [CrossRef]

83. Liu, C.; Li, X.; Chen, H. Application of water-assisted ultraviolet light processing on the inactivation of murine norovirus on blueberries. Int. J. Food Microbiol. 2015, 214, 18-23. [CrossRef] [PubMed]

84. Butot, S.; Cantergiani, F.; Moser, M.; Jean, J.; Lima, A.; Michot, L.; Putallaz, T.; Stroheker, T.; Zuber, S. UV-C inactivation of foodborne bacterial and viral pathogens and surrogates on fresh and frozen berries. Int. J. Food Microbiol. 2018, 275, 8-16. [CrossRef] [PubMed]

85. Huang, R.; Chen, H. Use of $254 \mathrm{~nm}$ ultraviolet light for decontamination of fresh produce and wash water. Food Control 2020, 109, 106926. [CrossRef]

86. Guo, S.; Huang, R.; Chen, H. Evaluating a Combined Method of UV and Washing for Sanitizing Blueberries, Tomatoes, Strawberries, Baby Spinach, and Lettuce. J. Food Prot. 2019, 82, 1879-1889. [CrossRef] [PubMed]

87. Liu, C.; Huang, Y.; Chen, H. Inactivation of Escherichia coli O157: H7 and Salmonella enterica on Blueberries in Water Using Ultraviolet Light. J. Food Sci. 2015. [CrossRef]

88. Huang, R.; Vries, D.D.; Chen, H. Strategies to enhance fresh produce decontamination using combined treatments of ultraviolet, washing and disinfectants. Int. J. Food Microbiol. 2018, 283, 37-44. [CrossRef]

89. Cho, M.; Choi, Y.; Park, H.; Kim, K.; Woo, G.J.; Park, J. Titanium dioxide/UV photocatalytic disinfection in fresh carrots. J. Food Prot. 2007, 70, 97-101. [CrossRef]

90. Ramesh, T.; Nayak, B.; Amirbahman, A.; Tripp, C.P.; Mukhopadhyay, S. Application of ultraviolet light assisted titanium dioxide photocatalysis for food safety: A review. Innov. Food Sci. Emerg. Technol. 2016, 38, 105-115. [CrossRef] 
91. Lee, M.; Shahbaz, H.; Kim, J.; Lee, H.; Lee, D.; Park, J. Efficacy of UV-TiO 2 photocatalysis technology for inactivation of Escherichia coli $\mathrm{K} 12$ on the surface of blueberries and a model agar matrix and the influence of surface characteristics. Food Microbiol. 2018, 76, 526-532. [CrossRef] [PubMed]

92. Karppinen, K.; Zoratti, L.; Nguyenquynh, N.; Häggman, H.; Jaakola, L. On the developmental and environmental regulation of secondary metabolism in Vaccinium spp. Berries. Front. Plant Sci. 2016, 7, 1-9. [CrossRef] [PubMed]

93. Wang, C.Y.; Chen, C.T.; Wang, S.Y. Changes of flavonoid content and antioxidant capacity in blueberries after illumination with UV-C. Food Chem. 2009, 117, 426-431. [CrossRef]

94. Bhavya, M.L.; Umesh Hebbar, H. Pulsed light processing of foods for microbial safety. Food Qual. Saf. 2017, 1, 187-201. [CrossRef]

95. Gómez-López, V.M.; Ragaert, P.; Debevere, J.; Devlieghere, F. Pulsed light for food decontamination: A review. Trends Food Sci. Technol. 2007, 18, 464-473. [CrossRef]

96. CFR-Code of Federal Regulations Title 21. Available online: https:/www.accessdata.fda.gov/scripts/cdrh/ cfdocs/cfcfr/CFRSearch.cfm?fr=179.41 (accessed on 1 September 2020).

97. Huang, Y.; Ye, M.; Cao, X.; Chen, H. Pulsed light inactivation of murine norovirus, Tulane virus, Escherichia coli O157: H7 and Salmonella in suspension and on berry surfaces. Food Microbiol. 2017, 61, 14-17. [CrossRef]

98. Cao, X.; Huang, R.; Chen, H. Evaluation of pulsed light treatments on inactivation of Salmonella on blueberries and its impact on shelf-life and quality attributes. Int. J. Food Microbiol. 2017, 260, 17-26. [CrossRef]

99. Huang, Y.; Sido, R.; Huang, R.; Chen, H. Application of water-assisted pulsed light treatment to decontaminate raspberries and blueberries from Salmonella. Int. J. Food Microbiol. 2015, 208, 43-50. [CrossRef]

100. Huang, R.; Chen, H. Comparison of Water-Assisted Decontamination Systems of Pulsed Light and Ultraviolet for Salmonella Inactivation on Blueberry, Tomato, and Lettuce. J. Food Sci. 2019, 84, 1145-1150. [CrossRef]

101. Huang, H.W.; Lung, H.M.; Yang, B.B.; Wang, C.Y. Responses of microorganisms to high hydrostatic pressure processing. Food Control 2014, 40, 250-259. [CrossRef]

102. Huang, R.; Ye, M.; Li, X.; Ji, L.; Karwe, M.; Chen, H. Evaluation of high hydrostatic pressure inactivation of human norovirus on strawberries, blueberries, raspberries and in their purees. Int. J. Food Microbiol. 2016, 223, 17-24. [CrossRef]

103. Li, X.; Chen, H.; Kingsley, D.H. The influence of temperature, pH, and water immersion on the high hydrostatic pressure inactivation of GI. 1 and GII. 4 human noroviruses. Int. J. Food Microbiol. 2013, 167, 138-143. [CrossRef] [PubMed]

104. Li, X.; Ye, M.; Neetoo, H.; Golovan, S.; Chen, H. Pressure inactivation of Tulane virus, a candidate surrogate for human norovirus and its potential application in food industry. Int. J. Food Microbiol. 2013, 162, 37-42. [CrossRef]

105. Kabir, N.; Aras, S.; Allison, A.; Adhikari, J.; Chowdhury, S.; Fouladkhah, A. Interactions of Carvacrol, Caprylic Acid, Habituation, and Mild Heat for Pressure-Based Inactivation of O157 and Non-O157 Serogroups of Shiga Toxin-Producing Escherichia coli in Acidic Environment. Microorganisms 2019, 7, 145. [CrossRef] [PubMed]

106. James, S.; James, C. Minimal Processing of Ready Meals, 2nd ed.; Elsevier Ltd.: Amsterdam, The Netherlands, 2014; ISBN 978-0-12-411479-1.

107. Odriozola-Serrano, I.; Aguiló-Aguayo, I.; Soliva-Fortuny, R.; Martín-Belloso, O. Pulsed electric fields processing effects on quality and health-related constituents of plant-based foods. Trends Food Sci. Technol. 2013, 29, 98-107. [CrossRef]

108. Wouters, P.C.; Alvarez, I.; Raso, J. Critical factors determining inactivation kinetics by pulsed electric field food processing. Trends Food Sci. Technol. 2001, 12, 112-121. [CrossRef]

109. Zhu, N.; Wang, Y.; Zhu, Y.; Yang, L.; Yu, N.; Wei, Y.; Zhang, H.; Sun, A. Design of a treatment chamber for low-voltage pulsed electric fi eld sterilization. Innov. Food Sci. Emerg. Technol. 2017, 42, 180-189. [CrossRef]

110. Jin, T.Z.; Yu, Y.; Gurtler, J.B. Effects of pulsed electric field processing on microbial survival, quality change and nutritional characteristics of blueberries. LWT Food Sci. Technol. 2017, 77, 517-524. [CrossRef]

111. Chen, J.; Tao, X.Y.; Sun, A.D.; Wang, Y.; Liao, X.J.; Li, L.N.; Zhang, S. Influence of pulsed electric field and thermal treatments on the quality of blueberry juice. Int. J. Food Prop. 2014, 17, 1419-1427. [CrossRef]

112. Zhu, N.; Yu, N.; Zhu, Y.; Wei, Y.; Hou, Y.; Zhang, H.; Sun, A.D. Identification of spoilage microorganisms in blueberry juice and their inactivation by a microchip pulsed electric field system. Sci. Rep. 2018, 8, 1-8. [CrossRef] 
113. Zhu, N.; Zhu, Y.; Yu, N.; Wei, Y.; Zhang, J.; Hou, Y.; Sun, A. Evaluation of microbial, physicochemical parameters and flavor of blueberry juice after microchip-pulsed electric field. Food Chem. 2019, 274, 146-155. [CrossRef] [PubMed]

114. Niemira, B.A. Cold Plasma Decontamination of Foods. Annu. Rev. Food Sci. Technol 2012, 3, 125-142. [CrossRef] [PubMed]

115. Lacombe, A.; Niemira, B.A.; Gurtler, J.B.; Fan, X.; Sites, J.; Boyd, G.; Chen, H. Atmospheric cold plasma inactivation of aerobic microorganisms on blueberries and effects on quality attributes. Food Microbiol. 2015, 46, 479-484. [CrossRef] [PubMed]

116. Lacombe, A.; Niemira, B.A.; Gurtler, J.B.; Sites, J.; Boyd, G.; Kingsley, D.H.; Li, X.; Chen, H. Nonthermal inactivation of norovirus surrogates on blueberries using atmospheric cold plasma. Food Microbiol. 2017, 63, 1-5. [CrossRef] [PubMed]

117. Dong, X.Y.; Yang, Y.L. A Novel Approach to Enhance Blueberry Quality during Storage Using Cold Plasma at Atmospheric Air Pressure. Food Bioprocess. Technol. 2019, 12, 1409-1421. [CrossRef]

118. Pathak, N.; Bovi, G.G.; Limnaios, A.; Fröhling, A.; Brincat, J.P.; Taoukis, P.; Valdramidis, V.P.; Schlüter, O. Impact of cold atmospheric pressure plasma processing on storage of blueberries. J. Food Process. Preserv. 2020, 44, e14581. [CrossRef]

119. Hou, Y.; Wang, R.; Gan, Z.; Shao, T.; Zhang, X.; He, M.; Sun, A. Effect of cold plasma on blueberry juice quality. Food Chem. 2019, 290, 79-86. [CrossRef]

120. Zhou, D.; Wang, Z.; Tu, S.; Chen, S.; Peng, J.; Tu, K. Effects of cold plasma, UV-C or aqueous ozone treatment on Botrytis cinerea and their potential application in preserving blueberry. J. Appl. Microbiol. 2019, 127, 175-185. [CrossRef]

121. Moreno, M.A.; Castell-Perez, M.E.; Gomes, C.; Silva, P.F.D.; Moreira, R.G. Quality of electron beam irradiation of blueberries (Vaccinium corymbosum L) at medium dose levels (1.0-3.2 kGy). LWT Food Sci. Technol. 2007, 40, 1123-1132. [CrossRef]

122. Parish, M.E.; Beuchat, L.R.; Suslow, T.V.; Harris, L.J.; Garrett, E.H.; Farber, J.N.; Busta, F.F. Methods to Reduce/Eliminate Pathogens from Fresh and Fresh-Cut Produce. Compr. Rev. Food Sci. Food Safe 2003, 2, 161-173. [CrossRef]

123. Thang, K.; Au, K.; Prakash, A. Effect of phytosanitary irradiation and methyl bromide fumigation on the physical, sensory, and microbiological quality of blueberries and sweet cherries. J. Sci. Food Agric. 2016, 96, 4382-4389. [CrossRef]

124. Lacombe, A.; Breard, A.; Hwang, C.; Hill, D.; Fan, X.; Huang, L.; Kwon, B.; Niemira, B.A.; Gurtler, J.B.; $\mathrm{Wu}$, V.C.H. Inactivation of Toxoplasma gondii on blueberries using low dose irradiation without affecting quality. Food Control 2017, 73, 981-985. [CrossRef]

125. Kong, Q.; Wu, A.; Qi, W.; Qi, R.; Mark, J.; Rasooly, R.; He, X. Effects of electron-beam irradiation on blueberries inoculated with Escherichia coli and their nutritional quality and shelf life. Postharvest Biol. Technol. 2014, 95, 28-35. [CrossRef]

126. Shahbaz, H.M.; Akram, K.; Ahn, J.J.; Kwon, J.H. Worldwide Status of Fresh Fruits Irradiation and Concerns about Quality, Safety, and Consumer Acceptance. Crit. Rev. Food Sci. Nutr. 2016, 56, 1790-1807. [CrossRef] [PubMed]

127. Nambeesan, S.U.; Doyle, J.W.; Capps, H.D.; Starns, C.; Scherm, H. Effect of Electronic Cold-PasteurizationTM (ECPTM) on Fruit Quality and Postharvest Diseases during Blueberry Storage. Horticulturae 2018, 4, 25. [CrossRef]

128. de São José, J.F.B.; de Andrade, N.J.; Mota, A.; Dantas Vanetti, M.C.; Stringheta, P.; Paes, J.B. Decontamination by ultrasound application in fresh fruits and vegetables. Food Control 2014, 45, 36-50. [CrossRef]

129. Rezek, J.A.; Šimunek, M.; Evacic, S.; Markov, K.; Smoljanic, G.; Frece, J. Influence of high power ultrasound on selected moulds, yeasts and Alicyclobacillus acidoterrestris in apple, cranberry and blueberry juice and nectar. Ultrasonics 2018, 83, 3-17. [CrossRef]

130. Zhu, J.; Wang, Y.; Li, X.; Li, B.; Liu, S.; Chang, N.; Jie, D.; Ning, C.; Gao, H.; Meng, X. Combined effect of ultrasound, heat, and pressure on Escherichia coli O157: H7, polyphenol oxidase activity, and anthocyanins in blueberry (Vaccinium corymbosum) juice. Ultrason. Sonochem. 2017, 37, 251-259. [CrossRef] 
131. Zhang, H.; Wang, S.; Goon, K.; Gilbert, A.; Nguyen Huu, C.; Walsh, M.; Nitin, N.; Wrenn, S.; Tikekar, R.V. Inactivation of foodborne pathogens based on synergistic effects of ultrasound and natural compounds during fresh produce washing. Ultrason. Sonochem. 2020, 64, 104983. [CrossRef]

132. De Simone, N.; Pace, B.; Grieco, F.; Chimienti, M.; Tyibilika, V.; Santoro, V.; Capozzi, V.; Colelli, G.; Spano, G.; Russo, P. Botrytis cinerea and Table Grapes: A Review of the Main Physical, Chemical, and Bio-Based Control Treatments in Post-Harvest. Foods 2020, 9, 1138. [CrossRef]

133. Takahashi, M.; Okakura, Y.; Takahashi, H.; Imamura, M. Heat-denatured lysozyme could be a novel disinfectant for reducing hepatitis A virus and murine norovirus on berry fruit. Int. J. Food Microbiol. 2018, 266, 104-108. [CrossRef] [PubMed]

134. Bambace, M.F.; Alvarez, M.V.; Moreira, M.D.R. Novel functional blueberries: Fructo-oligosaccharides and probiotic lactobacilli incorporated into alginate edible coatings. Food Res. Int. 2019, 122, 653-660. [CrossRef] [PubMed]

135. Xu, L.; Zhang, B.; Qin, Y.; Li, F.; Yang, S.; Lu, P.; Wang, L.; Fan, J. Preparation and characterization of antifungal coating films composed of sodium alginate and cyclolipopeptides produced by Bacillus subtilis. Int. J. Biol. Macromol. 2020, 143, 602-609. [CrossRef] [PubMed]

136. Pobiega, K.; Igielska, M.; W \lodarczyk, P.; Gniewosz, M. The use of pullulan coatings with propolis extract to extend the shelf life of blueberry (Vaccinium corymbosum) fruit. Int. J. Food Sci. Technol. 2020, 1-8. [CrossRef]

137. Songe, J.; Fan, L.; Forney, C.; Campbell-Palmer, L.; Fillmore, S. Effect of hexanal vapor to control postharvest decay and extend shelf-life of highbush blueberry fruit during controlled atmosphere storage. Can. J. Plant Sci. 2010, 90, 359-366. [CrossRef]

138. Crowe, K.M.; Bushway, A.; Davis-dentici, K. Impact of postharvest treatments, chlorine and ozone, coupled with low-temperature frozen storage on the antimicrobial quality of lowbush blueberries (Vaccinium angustifolium). LWT Food Sci. Technol. 2012, 47, 213-215. [CrossRef]

139. Kim, T.J.; Corbitt, M.P.; Silva, J.L.; Wang, D.S.; Jung, Y.; Spencer, B. Optimization of Hot Water Treatment for Removing Microbial Colonies on Fresh Blueberry Surface. J Food Sci. 2011. [CrossRef] [PubMed]

140. Kingsley, D.H.; Boyd, G.; Sites, J.; Niemira, B.A. Evaluation of 405-nm monochromatic light for inactivation of Tulane virus on blueberry surfaces. J Appl. Microbiol. 2017, 1017-1022. [CrossRef]

141. Horm, K.M.; Davidson, P.M.; Harte, F.M.; Souza, D.H.D. Survival and Inactivation of Human Norovirus Surrogates in Blueberry Juice by High-Pressure Homogenization. Foodborne Pathog. Dis. 2012, 9, 974-979. [CrossRef]

142. Bogdanov, T.; Tsonev, I.; Marinova, P.; Benova, E.; Rusanov, K.; Rusanova, M.; Atanassov, I.; Kozáková, Z.; Krčma, F. Microwave Plasma Torch Generated in Argon for Small Berries Surface Treatment. Appl. Sci. 2018, 8, 1870. [CrossRef]

143. Fan, L.; Martynenko, A.; Doucette, C.; Hughes, T.; Fillmore, S. Microbial Quality and Shelf Life of Blueberry Purée Developed Using Cavitation Technology. J. Food Sci. 2018, 83, 732-739. [CrossRef] [PubMed]

144. Mohideen, F.W.; Solval, K.M.; Li, J.; Zhang, J.; Chouljenko, A.; Chotiko, A.; Prudente, A.D.; Bankston, J.D.; Sathivel, S. Effect of continuous ultra-sonication on microbial counts and physico-chemical properties of blueberry (Vaccinium corymbosum) juice. LWT Food Sci. Technol. 2015, 60, 563-570. [CrossRef]

145. De, J.; Sreedharan, A.; Li, Y.; Gutierrez, A.; Brecht, J.K.; Sargent, S.A.; Schneider, K.R. Comparing the Efficacy of Postharvest Cooling Methods to Enhance Fruit Quality and Reduce Salmonella in Artificially Inoculated Southern Highbush Blueberry. Hort Technol. 2019, 1. [CrossRef]

Publisher's Note: MDPI stays neutral with regard to jurisdictional claims in published maps and institutional affiliations.

(C) 2020 by the authors. Licensee MDPI, Basel, Switzerland. This article is an open access article distributed under the terms and conditions of the Creative Commons Attribution (CC BY) license (http://creativecommons.org/licenses/by/4.0/). 